\title{
The response of methane and nitrous oxide fluxes to forest change in Europe
}

\author{
P. Gundersen ${ }^{1}$, J. R. Christiansen ${ }^{1,{ }^{* *}}$, G. Alberti ${ }^{2}$, N. Brüggemann ${ }^{3,{ }^{*}}$, S. Castaldi ${ }^{4}$, R. Gasche ${ }^{3}$, B. Kitzler ${ }^{5}$, \\ L. Klemedtsson ${ }^{6}$, R. Lobo-do-Vale ${ }^{7}$, F. Moldan $^{8}$, T. Rütting ${ }^{6}$, P. Schleppi ${ }^{9}$, P. Weslien ${ }^{6}$, and \\ S. Zechmeister-Boltenstern ${ }^{10}$ \\ ${ }^{1}$ Forest \& Landscape, University of Copenhagen, Rolighedsvej 23, 1958 Frederiksberg C, Denmark \\ ${ }^{2}$ CNR-IBIMET, Italy - Present address: Department of Agricultural and Environmental Sciences University of Udine, \\ via delle Scienze 208, 33100 Udine, Italy \\ ${ }^{3}$ Karlsruhe Institute of Technology, Institute of Meteorology and Climate Research, Atmospheric Environmental Research \\ (IMK-IFU), Kreuzeckbahnstaße. 19, 82467 Garmisch-Partenkirchen, Germany \\ ${ }^{4}$ Dipartimento di Scienze Ambientali, Seconda Università di Napoli, Caserta, Italy \\ ${ }^{5}$ Federal Research and Training Centre for Forests, Natural Hazards and Landscape (BFW), Austria \\ ${ }^{6}$ Department of Biological and Environmental Sciences, University of Gothenburg, P.O. Box 461, \\ 40530 Gothenburg, Sweden \\ ${ }^{7}$ Agronomy Institute, Technical University of Lisbon, Portugal \\ ${ }^{8}$ IVL Swedish Environmental Research Institute, Box 53021, 40014 Gothenburg, Sweden \\ ${ }^{9}$ Swiss Federal Institute for Forest, Snow and Landscape Research, Zürcherstr. 111, 8903 Birmensdorf, Switzerland \\ ${ }^{10}$ Institute of Soil Research,University of Natural Resources and Life Sciences, Peter-Jordanstrasse 82, 1190 Vienna, Austria \\ * currently at: Forschungszentrum Jülich GmbH, Institute of Bio- and Geosciences, Agrosphere (IBG-3), \\ 52425 Jülich, Germany \\ ** currently at: Department of Forest Sciences, University of British Columbia, Vancouver, BC, V6T1Z4, Canada
}

Correspondence to: P. Gundersen (pgu@life.ku.dk)

Received: 30 April 2012 - Published in Biogeosciences Discuss.: 29 May 2012

Revised: 7 September 2012 - Accepted: 12 September 2012 - Published: 17 October 2012

\begin{abstract}
Forests in Europe are changing due to interactions between climate change, nitrogen $(\mathrm{N})$ deposition and new forest management practices. The concurrent impact on the forest greenhouse gas (GHG) balance is at present difficult to predict due to a lack of knowledge on controlling factors of GHG fluxes and response to changes in these factors. To improve the mechanistic understanding of the ongoing changes, we studied the response of soil-atmosphere exchange of nitrous oxide $\left(\mathrm{N}_{2} \mathrm{O}\right)$ and methane $\left(\mathrm{CH}_{4}\right)$ at twelve experimental or natural gradient forest sites, representing anticipated future forest change. The experimental manipulations, one or more per site, included $\mathrm{N}$ addition (4 sites), changes of climate (temperature, 1 site; precipitation, 2 sites), soil hydrology (3 sites), harvest intensity (1 site), wood ash fertilisation (1 site), $\mathrm{pH}$ gradient in organic soil (1 site) and afforestation of cropland (1 site).
\end{abstract}

On average, $\mathrm{N}_{2} \mathrm{O}$ emissions increased by $0.06 \pm 0.03$ (range 0-0.3) $\mathrm{g} \mathrm{N}_{2} \mathrm{O}-\mathrm{N} \mathrm{m}^{-2} \mathrm{yr}^{-1}$ across all treatments on mineral soils, but the increase was up to 10 times higher in an acidic organic soil. Soil moisture together with mineral soil $\mathrm{C} / \mathrm{N}$ ratio and $\mathrm{pH}$ were found to significantly influence $\mathrm{N}_{2} \mathrm{O}$ emissions across all treatments. Emissions were increased by elevated $\mathrm{N}$ deposition, especially in interaction with increased soil moisture. High $\mathrm{pH}$ reduced the formation of $\mathrm{N}_{2} \mathrm{O}$, even under otherwise favourable soil conditions.

Oxidation (uptake) of $\mathrm{CH}_{4}$ was on average reduced from $0.16 \pm 0.02$ to $0.04 \pm 0.05 \mathrm{~g} \mathrm{CH}_{4}-\mathrm{C} \mathrm{m}^{-2} \mathrm{yr}^{-1}$ by the investigated treatments. The $\mathrm{CH}_{4}$ exchange was significantly influenced by soil moisture and soil $\mathrm{C} / \mathrm{N}$ ratio across all treatments, and $\mathrm{CH}_{4}$ emissions occurred only in wet or watersaturated conditions. 
For most of the investigated forest manipulations or natural gradients, the response of both $\mathrm{N}_{2} \mathrm{O}$ and $\mathrm{CH}_{4}$ fluxes was towards reducing the overall GHG forest sink. The most resilient forests were dry Mediterranean forests, as well as forests with high soil $\mathrm{C} / \mathrm{N}$ ratio or high soil $\mathrm{pH}$. Mitigation strategies may focus on (i) sustainable management of wet forest areas and forested peatlands, (ii) continuous forest cover management, (iii) reducing atmospheric $\mathrm{N}$ input and, thus, $\mathrm{N}$ availability, and (iv) improving neutralisation capacity of acid soils (e.g. wood ash application).

\section{Introduction}

European forests sequester atmospheric carbon (C) in biomass and soil at an estimated annual net rate of $109 \mathrm{Tg}$ (Luyssaert et al., 2010), which is equivalent to $10 \%$ of the European fossil fuel emissions. Moreover, compared to agricultural soils, forest soils generally function as a net sink for the strong greenhouse gas (GHG) methane $\left(\mathrm{CH}_{4}\right)$ and emit less of the even stronger GHG nitrous oxide $\left(\mathrm{N}_{2} \mathrm{O}\right)$, hence, having in general a net total GHG mitigation effect.

The radiative forcing of $\mathrm{CH}_{4}$ and $\mathrm{N}_{2} \mathrm{O}$ on a time horizon of $100 \mathrm{yr}$ is 25 and 298 times stronger than $\mathrm{CO}_{2}$, respectively. The atmospheric concentration of both gases has constantly risen since the late $1890 \mathrm{~s}$, amounting presently to a $158 \%$ and $19 \%$ increase, respectively, compared to pre-industrial levels (WMO, 2010). At present, these two greenhouse gases constitute $18 \%\left(\mathrm{CH}_{4}\right)$ and $6 \%\left(\mathrm{~N}_{2} \mathrm{O}\right)$ of the global radiative forcing in the atmosphere (not accounting for water vapour), and their role in the global warming is expected to increase in the future (WMO, 2010).

Recently, the first European Nitrogen Assessment (Sutton et al., 2011) stated that European forests were responsible for a net cooling effect, although the magnitude of this phenomenon is still associated with considerable uncertainty (Schulze et al., 2009; Butterbach-Bahl et al., 2011a). These studies have also pointed to the fact that enhanced $\mathrm{C}$ sequestration in European forests is in part a consequence of increased nitrogen $(\mathrm{N})$ deposition. However, the largest uncertainty on the net GHG balance of these ecosystems is related to the determination of annual budgets of $\mathrm{N}_{2} \mathrm{O}$ and $\mathrm{CH}_{4}$ and to feedback mechanisms between changes to forests and $\mathrm{CH}_{4}$ and $\mathrm{N}_{2} \mathrm{O}$ soil-atmosphere fluxes. Currently, the forested area in Europe is increasing annually by $0.3 \%$ and is expected to continue to increase by natural succession after abandonment of agricultural land or by active afforestation. Thus, the importance of forests for the European GHG balance will increase.

Current and future management strategies, such as replacement of coniferous with broadleaf species, restoration of natural water regimes to conserve and foster biodiversity, and modified and intensified management strategies towards use of wood for bioenergy, will contribute to altering the present GHG balance of $\mathrm{CH}_{4}$ and $\mathrm{N}_{2} \mathrm{O}$ for forests in combination with climate change (i.e. temperature increase and altered precipitation patterns) and air pollution. Limited scientific evidence is available to allow for an accurate prediction of forest changes in Europe and subsequent impacts on the balance of $\mathrm{CH}_{4}$ and $\mathrm{N}_{2} \mathrm{O}$ (Schulze et al., 2009).

The present work aims to contribute to filling this knowledge gap. We compiled annual fluxes of $\mathrm{N}_{2} \mathrm{O}$ and $\mathrm{CH}_{4}$ from forest soils at twelve sites across Europe ranging from Sweden to Portugal where manipulation or natural gradient effects on non- $\mathrm{CO}_{2}$ GHG fluxes were investigated.

The conceptual frame of our study consisted of external and internal drivers regulating GHG fluxes. The external drivers of forest change will alter soil conditions, termed internal drivers, leading to responses in $\mathrm{N}_{2} \mathrm{O}$ and $\mathrm{CH}_{4}$ fluxes. Based on recent literature reviews, we expect soil $\mathrm{pH}$, diffusion properties, $\mathrm{N}$ availability, soil temperature and water content to be the most important internal drivers affecting the exchange of these gases (Ball et al., 1997; Butterbach-Bahl et al., 2011a, b; Liu and Greaver, 2009; Machefert et al., 2002). The goal of this paper is to synthesise how changes of the external and internal drivers are connected to the exchange of $\mathrm{N}_{2} \mathrm{O}$ and $\mathrm{CH}_{4}$ in European forests. Based on this conceptual frame, the objectives of this study are: (i) to present the responses of $\mathrm{CH}_{4}$ and $\mathrm{N}_{2} \mathrm{O}$ to changes in external drivers; (ii) to identify interactions between external and internal soil drivers of $\mathrm{CH}_{4}$ and $\mathrm{N}_{2} \mathrm{O}$ fluxes, including feedback to external changes; (iii) to identify potential risks for increased emissions of $\mathrm{CH}_{4}$ and $\mathrm{N}_{2} \mathrm{O}$ due to expected future forest change as well as their sources and relative importance, stratified by area, forest type and management; and (iv) to propose mitigation options by managing external and internal drivers.

\section{Methods}

\subsection{Sites with forest change}

Results of the annual GHG exchange were compiled from 12 sites with manipulation experiments or observational gradients (Table 1) selected to represent multiple aspects of forest change across Europe (Fig. 1). Long-term experiments and well characterised sites were preferred, where possible, to avoid transient responses and due to the availability of soil and vegetation data. Field measurements of soil GHG exchange were established at all sites and for all treatments as part the NitroEurope project ( $\mathrm{C} 2$ sites) and designed specifically to address the objectives of this study. For studies over soil gradients, plots were established along the gradients according to soil characteristics to form treatments (e.g. in a soil hydrological gradient, separate plots were installed in a dry upland treatment (control) and a wetter lowland treatment). In total, 39 treatments (including controls) and 74 plots were investigated. Main site characteristics are 
Table 1. NitroEurope C2 sites (ordered north to south) - characteristics and treatments.

\begin{tabular}{|c|c|c|c|c|c|c|c|c|c|c|}
\hline Site & Code & Latitude & Longitude & $\begin{array}{l}\text { MAP } \\
(\mathrm{mm})\end{array}$ & $\begin{array}{l}\text { MAT } \\
\left({ }^{\circ} \mathrm{C}\right)\end{array}$ & Tree species & Soil type & Soil $\mathrm{pH}^{\mathrm{a}}$ & $\begin{array}{l}\text { Forest change treatment } \\
\text { or factor }\end{array}$ & $\begin{array}{l}\text { Reference for site } \\
\text { and treatment details }\end{array}$ \\
\hline Falköping, SE & FK & $58^{\circ} 76^{\prime} \mathrm{N}$ & $13^{\circ} 33^{\prime} \mathrm{E}$ & 620 & 5 & Silver birch & Histosol & $3.7-5.8^{\mathrm{b}}$ & $\mathrm{pH}$ gradient & Weslien et al. (2009) \\
\hline Gårdsjön, SE & GS & $58^{\circ} 40^{\prime} \mathrm{N}$ & $12^{\circ} 30^{\prime} \mathrm{E}$ & 1145 & 6.3 & Norway spruce & Podzol & 3.8 & $\begin{array}{l}\mathrm{N} \text { addition } \\
\text { Soil hydrology }\end{array}$ & Moldan and Wright (2011) \\
\hline Skogaryd, SE & SR & $58^{\circ} 23^{\prime} \mathrm{N}$ & $12^{\circ} 09^{\prime} \mathrm{E}$ & 881 & 8.4 & Norway spruce & Histosol & $4.5^{\mathrm{b}}$ & Wood ash & Klemedtsson et al. (2010) \\
\hline Klosterhede, DK & KH & $56^{\circ} 29^{\prime} \mathrm{N}$ & $8^{\circ} 24^{\prime} \mathrm{E}$ & 769 & 8.0 & Norway spruce & Podzol & 4.0 & $\mathrm{~N}$ addition & Gundersen (1998) \\
\hline Strødam, DK & ST & $55^{\circ} 57^{\prime} \mathrm{N}$ & $12^{\circ} 16^{\prime} \mathrm{E}$ & 657 & 7.8 & Beech & Arenosol & 3.5 & $\begin{array}{l}\text { Soil hydrology } \\
\text { pH gradient }\end{array}$ & Christiansen et al. (2012) \\
\hline $\begin{array}{l}\text { Vestskoven, DK (1) } \\
\text { (2) }\end{array}$ & $\begin{array}{l}\text { VS1 } \\
\text { VS2 }\end{array}$ & $55^{\circ} 42^{\prime} \mathrm{N}$ & $12^{\circ} 21^{\prime} \mathrm{E}$ & 594 & 7.9 & $\begin{array}{l}\text { Oak } \\
\text { Oak, N. spruce }\end{array}$ & Luvisol & $\begin{array}{l}5.3 \\
5.1\end{array}$ & $\begin{array}{l}\text { Soil hydrology } \\
\text { Tree species/stand age }\end{array}$ & $\begin{array}{l}\text { Christiansen et al. (2012) } \\
\text { Hansen et al. (2007) }\end{array}$ \\
\hline Höglwald, DE & HW & $48^{\circ} 17^{\prime} \mathrm{N}$ & $11^{\circ} 04^{\prime} \mathrm{E}$ & 850 & 7.6 & Norway spruce & Cambisol & 3.7 & Harvest intensity & Wu et al. $(2010,2011)$ \\
\hline Klausenleopoldsdorf, AT & KL & $48^{\circ} 07^{\prime} \mathrm{N}$ & $16^{\circ} 03^{\prime} \mathrm{E}$ & 768 & 7.6 & Beech & Dystric Cambisol & 4.6 & $\mathrm{~N}$ addition & Kaiser et al. (2010) \\
\hline Achenkirch, AT & $\mathrm{AK}$ & $47^{\circ} 34^{\prime} \mathrm{N}$ & $11^{\circ} 38^{\prime} \mathrm{E}$ & 1480 & 5.7 & Norway spruce & Chromic Cambisol & 6.5 & Soil warming & Schindlbacher et al. (2011) \\
\hline Alptal, CH & AT & $47^{\circ} 03^{\prime} \mathrm{N}$ & $8^{\circ} 43^{\prime} \mathrm{E}$ & 2300 & 6 & Norway spruce & Gleysol & 5.5 & $\mathrm{~N}$ addition & Hagedorn et al. (2001) \\
\hline Tolfa Allumiere, IT & $\mathrm{TA}$ & $42^{\circ} 11^{\prime} \mathrm{N}$ & $11^{\circ} 56^{\prime} \mathrm{E}$ & 729 & 13 & Strawberry tree & Andisol & 4.0 & Precipitation & Cotrufo et al. (2011) \\
\hline Herdade da Mitra, PT & HM & $38^{\circ} 31^{\prime} \mathrm{N}$ & $8^{\circ} 00^{\prime} \mathrm{W}$ & 669 & 15.5 & Cork oak & Haplic Cambisol & 5.0 & Precipitation & Shvaleva et al. (2011) \\
\hline
\end{tabular}

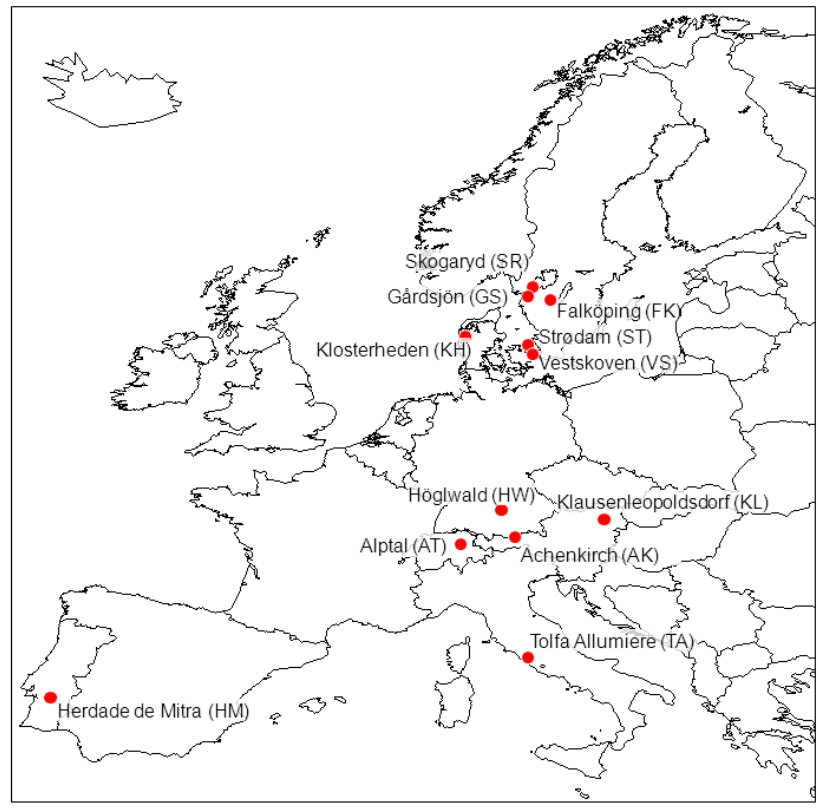

Fig. 1. Forest change sites in the NitroEurope project.

presented in Table 1 along with references to more detailed site information and in depth descriptions of the manipulation treatments.

The climate ranged from hemiboreal in Sweden with a mean annual air temperature (MAT) of $5^{\circ} \mathrm{C}$ to Mediterranean climate in Portugal with a MAT of $15.5^{\circ} \mathrm{C}$. Mean annual precipitation (MAP) ranged from a maximum of $2300 \mathrm{~mm}$ at Alptal (AT) to a minimum of $594 \mathrm{~mm}$ at Vestskoven (VS). Ambient $\mathrm{N}$ deposition ranged from 9 to $29 \mathrm{~kg} \mathrm{~N} \mathrm{ha}^{-1} \mathrm{yr}^{-1}$ at Gårdsjön (GS) and Höglwald (HW), respectively.

\subsubsection{Nitrogen addition}

For the study of responses to elevated $\mathrm{N}$ deposition, four ongoing $\mathrm{N}$ addition experiments were available (Table 1). Three of them - the GS site in Sweden, Klosterhede (KH), Denmark, and the AT site in Switzerland - were originally a part of the NITREX project (Wright et al., 1995). The selected forest stands were Norway spruce (Picea abies (L.) Karst.) stands with an age spanning 80 to $200 \mathrm{yr}$. $\mathrm{N}$ addition started in 1991-1994 with a monthly or event-based application rate of $25-35 \mathrm{~kg} \mathrm{Nha}^{-1} \mathrm{yr}^{-1}\left(\mathrm{NH}_{4} \mathrm{NO}_{3}\right)$. The fourth experiment - Klausenleopoldsdorf (KL), Austria - comprised a similar treatment with addition of $50 \mathrm{~kg} \mathrm{~N} \mathrm{ha}^{-1} \mathrm{yr}^{-1}$ since 2006 in a 65 -yr-old beech (Fagus sylvatica L.) stand. Ambient $\mathrm{N}$ deposition was $9-20 \mathrm{~kg} \mathrm{Nha}^{-1} \mathrm{yr}^{-1}$ at the four sites, leading to a total $\mathrm{N}$ deposition on the manipulated plots between 45 and $65 \mathrm{~kg} \mathrm{Nha}^{-1} \mathrm{yr}^{-1}$. The experiment at $\mathrm{KH}$ had a paired plot design, whereas at KL a block design with six replicates was implemented. The experiments at AT and GS were paired catchment studies. At AT the studied catchments were 0.15 ha and at GS they were $>0.5$ ha. At both sites, wet and dry areas were included, and sampled as separate treatments at GS.

\subsubsection{Climate change}

The response to changes in precipitation regime were studied by throughfall manipulations at two Mediterranean sites initiated in 2004: Tolfa Allumiere (TA), Italy (with GHG sampling between 2006-2007), and Herdade da Mitra (HM), Portugal (with GHG sampling between 2008-2009), with evergreen woodlands dominated by strawberry tree (Arbutus unedo L.) and cork oak (Quercus suber L.), respectively. At TA and HM a dry treatment with an exclusion of 20-26\% of the annual throughfall was established, using partial roofs and plastic covers installed $0.3-1.6 \mathrm{~m}$ above the soil surface. Throughfall collected at the dry treatment was redistributed by suspended sprinklers or irrigation pipes with drip emitters on other plots to obtain a wet treatment at HM and to keep soil water content above $10 \%$ during dry summer at TA. Both sites were established as a block design with three replicates, including also ambient control plots. 
Table 2. Methods for determination of GHG fluxes.

\begin{tabular}{|c|c|c|c|c|c|c|c|c|c|}
\hline Site & Code & Period (mm.yy) & Method & $\begin{array}{l}\text { Chambers per } \\
\text { treatment }\end{array}$ & Frequency & $\begin{array}{l}\text { Area }^{\mathrm{a}} \\
\mathrm{m}^{2}\end{array}$ & $\begin{array}{l}\text { No. of conc. } \\
\text { measurements }\end{array}$ & $\begin{array}{l}\text { Flux calculation } \\
\text { method }^{\mathrm{c}}\end{array}$ & $\begin{array}{l}\text { Reference to GHG } \\
\text { method details }\end{array}$ \\
\hline Falköping & FK & $08.94-10.97$ & manual & $2-3$ & weekly/fortnightly & 0.5 & 2 & linear & Weslien et al. (2009) \\
\hline Gårdsjön & GS & $06.06-07.07$ & manual & $4-6$ & fortnightly & $1.0-1.6$ & 4 & linear & Klemedtsson et al. (1997) \\
\hline Skogaryd & SR & $06.06-06.08$ & manual & 12 & fortnightly & 3.1 & 4 & linear & Klemedtsson et al. (2010) \\
\hline Klosterhede & $\mathrm{KH}$ & $06.07-10.08$ & manual & 8 & monthly & 0.6 & 4 & linear & Christiansen (2010) \\
\hline Strødam & ST & $05.07-08.09$ & manual & $6-9$ & fortnightly & $0.4-0.7$ & 4 & linear & Christiansen et al. (2012) \\
\hline Vestskoven & VS1 & $05.07-10.08$ & manual & 9 & fortnightly & 0.66 & 4 & linear & Christiansen et al. (2012) \\
\hline Dry - wet & VS2 & $02.08-04.10$ & manual & 9 & monthly & 0.66 & 4 & linear & Christiansen and \\
\hline Age $\times$ species & & & & & & & & & Gundersen (2011) \\
\hline Höglwald & HW & $01.00-12.07$ & auto & 5 & 2-hourly & 1.25 & 4 & linear & Wu et al. (2011) \\
\hline Klausenleopoldsdorf & KL & 03.06-12.09 & manual & 3 & fortnightly & 3.0 & 4 & linear & Kitzler et al. (2006) \\
\hline Achenkirch & $\mathrm{AK}$ & 05.06-12.09 & & 9 & fortnightly & 0.28 & 4 & linear & $\begin{array}{l}\text { Kitzler personal } \\
\text { communication } \\
\text { (April 2012) }\end{array}$ \\
\hline Alptal & AT & 03.07-11.09 & manual & 6 & monthly & 0.37 & 3 & linear & $\begin{array}{l}\text { Schleppi personal } \\
\text { communication } \\
\text { (April 2012) }\end{array}$ \\
\hline Tolfa Allumiere & $\mathrm{TA}$ & $04.05-08.06$ & manual & 9 & fortnightly & 0.16 & 3 & linear & Castaldi et al. (2004) \\
\hline Herdade da Mitra & HM & $04.08-05.09$ & manual & 6 & monthly & 1.27 & 3 & linear & Shvaleva et al. (2011) \\
\hline
\end{tabular}

The response to elevated temperature was studied in a soil warming experiment established in 2004 at Achenkirch (AK), Austria, in a 130-yr-old Norway spruce dominated stand. Soil warming $+4{ }^{\circ} \mathrm{C}$ at $5 \mathrm{~cm}$ depth was maintained in the vegetation period by heating cables installed at $3 \mathrm{~cm}$ depth, $7.5 \mathrm{~cm}$ apart. Paired warmed and control plots $(2 \times$ $2 \mathrm{~m}$ ) were established in three replicates.

\subsubsection{Land-use change}

We considered "land-use change" as the changes of longterm influences (rotation length or longer) on soil processes, such as afforestation on cropland, the choice of tree species and changes in drainage. Two chronosequences of afforestation on cropland were studied in Denmark, one with Norway spruce and one with pedunculate oak (Quercus robur L.) at Vestskoven (VS1), where young (12-15 yr) and older (40 yr) stands of each species were compared. Soils were still affected by previous liming and fertilisation. In the same area, another oak stand planted on a gentle slope, comprising a hydrological gradient, was studied (VS2). After agricultural activities had ceased, the drainage system gradually failed and a small temporary pond emerged at the low end of the slope. A similar slope was selected at Strødam (ST), Denmark, in a 200-yr-old beech forest (unmanaged since 1945) and used to represent a natural undisturbed hydrological gradient. At these two sites (VS2, ST), measurements were done in transects along the hydrological gradients and were delineated for this study to form dry (well-drained upland) treatments (control) and wet treatments (permanently moist soils). Due to soil $\mathrm{pH}$ differences probably caused by groundwater inflow versus outflow zones, the wet treatment at ST could be further separated as wet- $\mathrm{pH}<4$ and wet-pH $>4$.

\subsubsection{Forest management}

We included two aspects of forest management, harvest intensity and fertilisation/re-use of wood ash, both relevant in scenarios with increased bioenergy extraction from forests. At the HW site in Germany, clear-cut and selective cutting were compared in a 100-yr-old Norway spruce stand. In February 2000, one plot was clear-cut while a second plot was selectively cut with approximately $20 \%$ of the basal area removed. The clear-cut and the gaps formed underneath the remaining spruce trees in the selective-cutting treatment were planted with beech seedlings. A third intact Norway spruce stand remained as control. The soil at $\mathrm{HW}$ is acidic $(\mathrm{pH}<4)$ and $\mathrm{N}$-saturated due to long-term high atmospheric nitrogen input of c. $30 \mathrm{~kg} \mathrm{Nha}^{-1} \mathrm{yr}^{-1}$ (Huber et al., 2004). As the treatment response we report a mean for the first $3 \mathrm{yr}$ after the disturbance, since that period exhibits a clear response to the clear-cut treatment.

Addition of hardened and crushed wood ash with a $\mathrm{pH}\left(\mathrm{H}_{2} \mathrm{O}\right)$ of $13\left(3.3 \mathrm{t}\right.$ ash $\left.\mathrm{ha}^{-1}\right)$ was studied in a random block design at Skogaryd (SR), Sweden, on a drained Histosol afforested with Norway spruce $60 \mathrm{yr}$ after abandonment of agricultural use (Klemedtsson et al., 2010). Wood ash was spread by hand in August 2006, and measurements of GHG fluxes were conducted between July 2006 and June 2008. Wood ash clearly affected soil pH. To further illustrate the long-term effect of $\mathrm{pH}$ differences, another drained Histosol site at Falköping (FK), Sweden, with a Silver birch (Betula pendula Roth) forest was studied. Here, soil GHG fluxes were measured in plots along a natural $\mathrm{pH}$ gradient, ranging from 3.6-5.8, with the high $\mathrm{pH}$ taken as the control treatment in our analysis. 
Table 3. Nitrogen deposition, soil characteristics and greenhouse gas exchange for control treatments and the response $\left(\Delta \mathrm{N}_{2} \mathrm{O}, \Delta \mathrm{CH}_{4}\right)$ to the forest change treatments (n.d. = not determined; n.s. = not significant).

\begin{tabular}{|c|c|c|c|c|c|c|c|c|c|c|c|c|c|c|c|}
\hline Site & Treatment & Code & $\begin{array}{l}\mathrm{N} \text { deposition } \\
\mathrm{g} \mathrm{N} \mathrm{m}^{-2} \mathrm{yr}^{-1}\end{array}$ & $\begin{array}{r}\mathrm{SOC}^{\mathrm{a}} \\
\mathrm{kgCm}\end{array}$ & $\begin{array}{r}\text { Soil } \mathrm{T}^{\mathrm{b}} \\
{ }^{\circ} \mathrm{C}\end{array}$ & $\begin{array}{l}\text { Soil moisture } \\
\text { v/v }\end{array}$ & $\begin{array}{l}\text { Bulk density } \\
\mathrm{g} \mathrm{cm}^{-3}\end{array}$ & $\begin{array}{r}\mathrm{C} / \mathrm{N} \text {-org } \\
\mathrm{gC}\end{array}$ & $\underset{\mathrm{N}^{-1}}{\mathrm{C} / \mathrm{N}-\mathrm{ms}^{\mathrm{c}}}$ & $\begin{array}{l}\mathrm{N}_{2} \mathrm{O}^{\mathrm{d}} \\
\mathrm{gN} \mathrm{m}^{-}\end{array}$ & ${ }_{\mathrm{yr}^{-1}}^{\Delta \mathrm{N}_{2} \mathrm{O}}$ & $\begin{array}{r}\text { Treatm. per yr and } \\
\text { significance }\end{array}$ & $\begin{array}{l}\mathrm{CH}_{4}^{\mathrm{d}} \\
\mathrm{gC} \mathrm{m}^{-2}\end{array}$ & $\begin{array}{l}\Delta \mathrm{CH}_{4}^{-1} \\
\mathrm{yr}^{-1}\end{array}$ & $\begin{array}{r}\text { Treatm. per yr } \\
\text { and significance }\end{array}$ \\
\hline \multicolumn{16}{|l|}{$\mathrm{N}$ addition } \\
\hline Klosterhede & $+35 \mathrm{kgN}$ & $\mathrm{KH}$ & 1.5 & 13.2 & 8.8 & 25 & 1.29 & 33 & 30 & 0.001 & 0.004 & $1-2,16$ & -0.05 & 0.005 & 16 \\
\hline Alptal & $+35 \mathrm{kgN}$ & $\mathrm{AT}$ & 1.7 & 8.9 & 7.8 & 24 & 0.42 & 21 & 18 & 0.002 & 0.007 & $14^{\circ}-16^{\circ}$, all & -0.03 & 0.08 & $14-16$ \\
\hline Klausenleopoldsdorf & $+50 \mathrm{kgN}$ & $\mathrm{KL}$ & 1.4 & 18.5 & 9.7 & 36 & 0.83 & 43 & 16 & 0.07 & 0.05 & $1-2^{*}, 3^{* *}$ & -0.19 & 0.04 & $1-3,2^{*}$ \\
\hline \multirow[t]{2}{*}{ Gårdsjön } & $+35 \mathrm{kgN}$ dry & GS & 0.9 & 19.0 & 8.5 & 31 & 0.78 & 42 & 34 & 0.003 & 0.02 & $1-2,16^{* *}$ & -0.23 & 0.11 & $16^{* *}$ \\
\hline & $+35 \mathrm{kgN}$ wet & & 0.9 & 17.6 & 8.5 & n.d. & 0.78 & 36 & 23 & -0.004 & 0.23 & $1-2,16^{* *}$ & -0.05 & 0.10 & $16^{* *}$ \\
\hline \multicolumn{16}{|l|}{ Climate change } \\
\hline Achenkirch & soil $+4^{\circ} \mathrm{C}$ & $\mathrm{AK}$ & 1.1 & 28.3 & 6.4 & 45 & 1.26 & n.d. & 17 & 0.04 & 0.02 & $1-4^{* * * *}$ & -0.13 & 0.01 & $1-4^{* *}$ \\
\hline \multirow[t]{2}{*}{ Tolfa Allumiere } & + rain & TA & 0.6 & 17.4 & 13.5 & 14 & 0.91 & 36 & 25 & $\approx 0$ & 0 & $3-4$ & -0.24 & 0.01 & $3-4$ \\
\hline & - rain & & & & & & & & & & 0 & $3-4$ & & 0.06 & $3-4$ \\
\hline \multirow[t]{2}{*}{ Herdade da Mitra } & + rain & HM & 0.5 & & 19 & 12 & 1.18 & n.d. & 19 & 0.0004 & 0.004 & $5-6$ & -0.19 & -0.02 & $5-6$ \\
\hline & - rain & & & & & & & & & & -0.0006 & $5-6$ & & 0.01 & $5-6$ \\
\hline \multicolumn{16}{|l|}{ Land-use change } \\
\hline \multirow[t]{2}{*}{ Strødam } & dry vs. wet & ST & 1.5 & 3.9 & 9.8 & 30 & 0.90 & 29 & 18 & 0.04 & 0.03 & * & -0.06 & 0.75 & **** \\
\hline & $\begin{array}{l}\text { dry vs. wet at } \\
\mathrm{pH}<4\end{array}$ & & 1.5 & 3.9 & 9.8 & 30 & 0.90 & 29 & 18 & 0.04 & 0.05 & $\circ$ & -0.09 & 0.01 & n.s. \\
\hline Vestskoven & dry vs. wet & VS1 & 1.2 & 8.0 & 9.3 & 39 & 1.28 & 34 & 11 & 0.06 & 0.27 & * & -0.02 & 0.39 & 。 \\
\hline \multirow[t]{2}{*}{ Vestskoven } & tree species & VS2 & 1.0 & 3.1 & 8.4 & 32 & 1.46 & 34 & 11 & 0.03 & 0.005 & n.s. & -0.09 & 0.05 & * \\
\hline & stand age & & & & & & & & & & -0.02 & *** & & 0.04 & n.s. \\
\hline \multicolumn{16}{|l|}{ Forest management } \\
\hline \multirow[t]{2}{*}{ Höglwald } & clear-cut & HW & 2.6 & 7.4 & 7.2 & 30 & 0.99 & 23 & 16 & 0.05 & 0.34 & $1-5^{* *}, 6^{*}, 7-8$ & -0.10 & 0.07 & $1-8^{* * *}$ \\
\hline & selective cutting & & & & & & & & & & 0.03 & $1-5^{*}, 6-8$ & & -0.01 & $1-8$ \\
\hline Skogaryd & $3.3 \mathrm{tash}$ & SR & 0.8 & 27.7 & 8.3 & n.d. & 0.19 & 23 & - & 0.26 & -0.11 & $1-2^{*}$ & -0.33 & -0.02 & $1,2^{*}$ \\
\hline \multirow[t]{2}{*}{ Falköping } & pH 5.8 vs. 4.6 & FK & 0.8 & 9.2 & 6.2 & 47 & 0.24 & 51 & - & 0.67 & 0.75 & * & -0.17 & 0.09 & * \\
\hline & pH 5.8 vs. 3.7 & & & & & & & & & & 2.56 & * & & 0.20 & * \\
\hline
\end{tabular}

Soil organic carbon pool: organic horizon $+0-30 \mathrm{~cm}$ in mineral soil.

b Soil temperature $\left({ }^{\circ} \mathrm{C}\right)$ at $5 \mathrm{~cm}$ below the surface.

Mean over the depth $0-20 \mathrm{~cm}$ of the mineral soil.

Annual mean fluxes of $\mathrm{N}_{2} \mathrm{O}$ and $\mathrm{CH}_{4}$ soil exchange measured for the control plots during the NitroEurope project.

${ }^{\mathrm{e}}$ Treatment years where GHG exchange was measured and the significance of the response:

${ }^{\circ} p<0.1 ;{ }^{*} p<0.05 ;{ }^{* *} p<0.01 ; * * * 1$; $p<0.001 ;$ n.s. not significant. For the studies over gradient, the significance of the gradient factor is displayed.

\subsection{Gas exchange measurements}

A common minimum protocol for gas sampling in the field, gas analysis and criteria for conversion of gas concentration to fluxes was agreed on among the participants of the NitroEurope Component 2 (C2) for the manipulation experiments. All GHG fluxes were measured using manually operated closed static chambers measured at weekly to monthly intervals except at the HW site, where automated closed static chambers were sampled on a 2-hourly basis. The chamber design, chamber number as well as the sampled area per treatment varied between sites (Table 2). In total, soil GHG exchange was measured from 248 chambers. Some sites continued gas flux measurements that started prior to the NitroEurope project period, but at most sites chambers were installed according to the protocol after 2006, and measurements started a couple of months later. Measurements were done for one year at four sites and two or more years at the other sites (Table 2). In our analyses we used the average flux of $\mathrm{N}_{2} \mathrm{O}$ and $\mathrm{CH}_{4}\left(\mathrm{~g} \mathrm{~m}^{-2} \mathrm{yr}^{-1}\right)$ per treatment (Table 3), along with site and soil characteristics determined in each treatment. The original flux data obtained were uploaded to a common database (http://nitroeuropedata.ceh.ac.uk).

Greenhouse gas fluxes measured with static chambers are susceptible to multiple sources of error from chamber design, chamber handling, sampling protocol and subsequent flux calculation (e.g. Rochette and Eriksen-Hamel, 2008). Improper use of fans to mix chamber headspace and linear flux calculation leads to underestimation of the absolute flux out of the soil (Christiansen et al., 2011). This underestima- tion of the GHG flux by static chambers is critical in terms of establishing budgets, however less so in relation to testing treatment effects as is the case in this study (Rochette and Eriksen-Hamel, 2008). The agreement on a common minimum protocol was meant to reduce the uncertainties and improve the comparability of the GHG fluxes measured across sites. Hence, we expect that uncertainties related to site specific designs were minimal compared to the spatiotemporal variability encountered at the individual sites.

\subsection{Calculations and statistics}

Treatment responses are reported here as the absolute difference in gas exchange fluxes between control and treatment. Response ratios were difficult to use due to control fluxes being close to zero at several sites. Treatment responses were tested for each treatment year with measurements by the statistical method appropriate for the design of each experiment and are reported in Table 3 .

The influence of site and soil characteristics on mean annual gas exchange fluxes were explored by stepwise regression with the SAS software version 9.2 using the REG procedure (SAS Institute Inc., Cary, North Carolina, USA, 2008), first using data from control plots and then from all treatments on mineral soil. In the first analysis the land-use change sites were represented by the oldest stands and those on upland dry soils as control plots. In the stepwise regression analyses, we considered the influence of MAT, MAP, throughfall precipitation, $\mathrm{N}$ deposition and the following soil parameters: bulk density, $\mathrm{pH}$ (in $0.01 \mathrm{MCaCl}_{2}$ ), and $\mathrm{C} / \mathrm{N}$ 
Table 4. The results of the stepwise regression analyses for control plots $(n=13)$ only and all plots (treatments + controls, $n=30)$. Only significant $(p<0.05$; bold) and marginal significant effects $(p<0.1)$ are shown.

\begin{tabular}{|c|c|c|c|c|c|c|c|c|}
\hline & $\mathrm{N}_{2} \mathrm{O}$ & & & & $\mathrm{CH}_{4}$ & & & \\
\hline & Control & & All & & Control & & All & \\
\hline Factor & $r^{\mathrm{a}}$ & $p^{\mathrm{b}}$ & $r$ & $p$ & $r$ & $p$ & $r$ & $p$ \\
\hline Soil moisture & - & - & 0.66 & $<0.0001$ & 0.56 & 0.059 & 0.48 & 0.007 \\
\hline $\mathrm{C} / \mathrm{N}^{\mathrm{c}}$ & -0.63 & 0.027 & -0.33 & 0.0013 & - & - & -0.37 & 0.021 \\
\hline Soil $\mathrm{pH}^{\mathrm{c}}$ & - & - & -0.28 & 0.025 & - & - & & - \\
\hline Throughfall amount & - & - & & - & - & - & -0.26 & 0.082 \\
\hline Overall model ${ }^{\mathrm{d}}$ & & 0.027 & & $<0.0001$ & _- & _- & & 0.0020 \\
\hline
\end{tabular}

ratio from the top mineral soil $(0-20 \mathrm{~cm})$, soil organic carbon $(\mathrm{SOC} ; 0-30 \mathrm{~cm})$ as well as soil moisture and soil temperature (at ca. $5 \mathrm{~cm}$ depth). Log-transformed $\mathrm{N}_{2} \mathrm{O}$ and $\mathrm{CH}_{4}$ fluxes and reciprocal values of mineral soil $\mathrm{C} / \mathrm{N}$ ratios were used in order to fulfil the assumptions of the stepwise linear regression analyses. Time series data were represented as mean values over the gas exchange measurement period.

\section{Results}

\section{$3.1 \quad \mathrm{~N}_{2} \mathrm{O}$ responses}

All the investigated forest soils acted as sources of $\mathrm{N}_{2} \mathrm{O}$, except for a small net negative flux of $-0.004 \mathrm{~g} \mathrm{~N}_{2} \mathrm{O}$ $\mathrm{N} \mathrm{m}^{-2} \mathrm{yr}^{-1}$ at the wet control in GS (Table 3). The maximum emission of $0.67 \mathrm{~g} \mathrm{~N}_{2} \mathrm{O}-\mathrm{N} \mathrm{m}^{-2} \mathrm{yr}^{-1}$ occurred from the drained organic soil at FK, Sweden (Table 3). The other Swedish site on organic soil (SR) had emission rates ranging from 0.16 to $0.26 \mathrm{~g} \mathrm{~N}_{2} \mathrm{O}-\mathrm{N} \mathrm{m}^{-2} \mathrm{yr}^{-1}$. For mineral upland soils, the mean ( \pm standard error of the mean) was $0.03 \pm$ $0.01 \mathrm{~g} \mathrm{~N}_{2} \mathrm{O}-\mathrm{N} \mathrm{m}^{-2} \mathrm{yr}^{-1}$, with a maximum of $0.07 \mathrm{~g} \mathrm{~N}_{2} \mathrm{O}$ $\mathrm{N} \mathrm{m}^{-2} \mathrm{yr}^{-1}$ at KL. Stepwise regression analysis including only control plots on mineral soil revealed a significant negative correlation between mineral soil $\mathrm{C} / \mathrm{N}$ ratio and $\mathrm{N}_{2} \mathrm{O}$ flux (Table 4).

Overall, the response of $\mathrm{N}_{2} \mathrm{O}$ fluxes to treatments was generally positive (Table 3, Fig. 2), and again the organic soils at FK (with the highest flux in the control treatment) exhibited the highest flux changes (up to $2.6 \mathrm{~g} \mathrm{~N}_{2} \mathrm{O}-\mathrm{N} \mathrm{m}^{-2} \mathrm{yr}^{-1}$ ) over a soil $\mathrm{pH}$ gradient. The responses increased with the level observed on the control $\left(R^{2}=0.64, p<0.001\right)$. The mean $\mathrm{N}_{2} \mathrm{O}$ emission from mineral upland soils for all treatments was $0.06 \pm 0.03 \mathrm{~g} \mathrm{~N}_{2} \mathrm{O}-\mathrm{N} \mathrm{m}^{-2} \mathrm{yr}^{-1}$, and the response of $\mathrm{N}_{2} \mathrm{O}$ to treatments ranged from no significant change at several sites to $0.34 \mathrm{~g} \mathrm{~N}_{2} \mathrm{O}-\mathrm{N} \mathrm{m}^{-2} \mathrm{yr}^{-1}$ (Fig. 2). Even within groups of similar manipulation types, e.g. $\mathrm{N}$ addition, responses varied by orders of magnitude (Fig. 2). The responses on mineral soils alone also increased with the level observed on the control $\left(R^{2}=0.31, p<0.03\right)$ when excluding GS wet where the response was exceptionally strong. The largest treatment re- sponse on mineral soil occurred after clear-cut at HW, but this was a transient response. After reaching the highest emission in the second year after clear-cutting, emissions gradually declined to pre-harvest levels in the sixth year (data not shown).

The stepwise regression analysis including all control and treatment plots on mineral soils showed that a combination of soil moisture, mineral soil $\mathrm{C} / \mathrm{N}$ ratio and soil $\mathrm{pH}$ could best predict $\mathrm{N}_{2} \mathrm{O}$ emissions (Table 4).

\section{2 $\mathrm{CH}_{4}$ responses}

At all control plots, except the AT site (Table 3), mean $\mathrm{CH}_{4}$ fluxes were negative (at a mean of $-0.14 \pm 0.02 \mathrm{~g} \mathrm{CH}_{4}$ $\mathrm{C} \mathrm{m}^{-2} \mathrm{yr}^{-1}$ ), i.e. the soil generally acted as a sink of atmospheric $\mathrm{CH}_{4}$ and ranged from a maximum uptake of $-0.33 \mathrm{~g} \mathrm{CH}_{4}-\mathrm{C} \mathrm{m}^{-2} \mathrm{yr}^{-1}$ at the drained organic soil at SR to a small net emission of $0.03 \mathrm{~g} \mathrm{CH}_{4}-\mathrm{C} \mathrm{m}^{-2} \mathrm{yr}^{-1}$ at the wet AT site. The stepwise regression including only control plots on mineral soils indicated that soil moisture was the most important factor, although not statistically significant $(P=0.059)$ (Table 4).

With the exception of three sites, treatments generally increased net $\mathrm{CH}_{4}$ exchange, meaning that either $\mathrm{CH}_{4}$ oxidation was reduced or $\mathrm{CH}_{4}$ emission increased (Fig. 3). The mean $\mathrm{CH}_{4}$ flux calculated for all the treatment sites (excluding control sites) was $-0.04 \pm 0.05 \mathrm{~g} \mathrm{CH}_{4}-\mathrm{C} \mathrm{m}^{-2} \mathrm{yr}^{-1}$, indicating an overall four-fold reduction of $\mathrm{CH}_{4}$ uptake. The response to manipulations was minor at several sites, but reached $0.75 \mathrm{~g} \mathrm{CH}_{4}-\mathrm{C} \mathrm{m}^{-2} \mathrm{yr}^{-1}$ (Fig. 3) at the hydrological gradient site, ST. In fact, major responses to manipulation, excluding the organic soils, were all observed at the sites with wet soil conditions (AT, GS, VS1 and ST), where a switch from net $\mathrm{CH}_{4}$ uptake in upland soils (control plots, except at AT) to net $\mathrm{CH}_{4}$ emission in the wet parts occurred. Even within groups of similar manipulation types, e.g. $\mathrm{N}$ addition or $\mathrm{pH}$ gradients, responses varied markedly (Fig. 3) and the responses were not related to the level observed on the control plots. The treatments that stimulated $\mathrm{CH}_{4}$ uptake were additional precipitation at $\mathrm{HM}$, selective cutting at $\mathrm{HW}$ and wood ash addition at SR (Fig. 3).

The stepwise regression analysis for $\mathrm{CH}_{4}$ on all plots included a combination of soil factors similar to $\mathrm{N}_{2} \mathrm{O}$ (Table 4). Soil water content and mineral soil $\mathrm{C} / \mathrm{N}$ ratio could explain the variation in $\mathrm{CH}_{4}$ fluxes observed at a significant level (Table 4).

\section{Discussion}

\subsection{Factors controlling $\mathrm{N}_{2} \mathrm{O}$ emissions from forest soils}

Our data (Table 3, Fig. 2) emphasise the large variability encountered when dealing with $\mathrm{N}_{2} \mathrm{O}$ fluxes from soils reported in numerous studies (e.g. Pilegaard et al., 2006; Skiba et al., 2009). Based on the diverse assemblage of forest sites and treatments, we discuss the main soil as factors (and their 


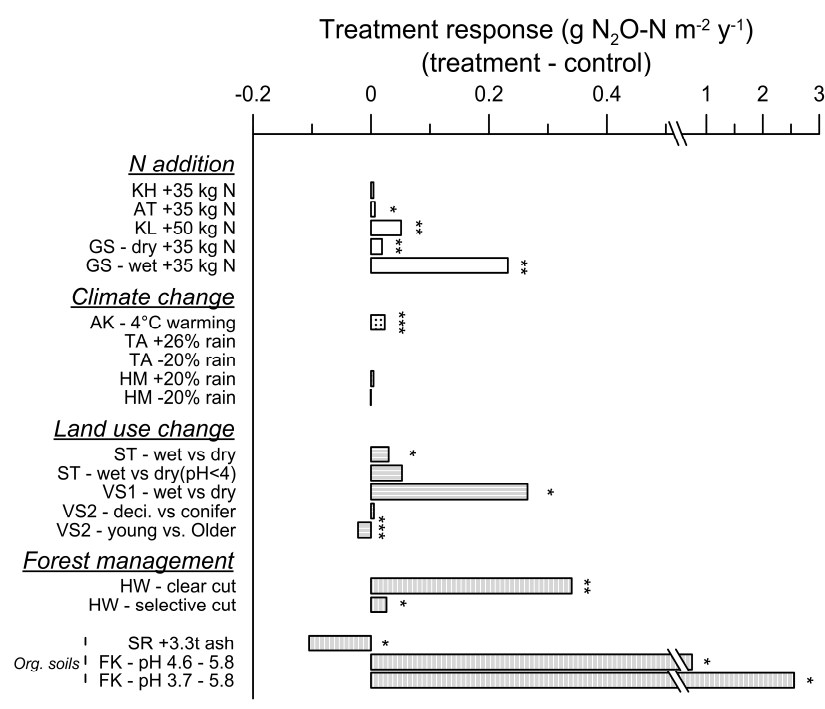

Fig. 2. Response of $\mathrm{N}_{2} \mathrm{O}$ gas exchange to forest change (treatment minus control). Site codes and treatments are explained in Table 1. Stars indicate the level of significance for the treatment effect $\left(^{*}\right.$ : $p<0.05$; $^{* *}: p<0.01$; $\left.^{* * *}: p<0.001\right)$.

interaction) that may control the large variability in $\mathrm{N}_{2} \mathrm{O}$ emission. The two Swedish organic soil sites investigated (SR, FK) had much higher $\mathrm{N}_{2} \mathrm{O}$ emissions (a factor of 5 to 10) and greater absolute treatment responses than sites on mineral soils (Table 3). High $\mathrm{N}_{2} \mathrm{O}$ emissions from organic soils are known, and a recent review discussed controlling factors on this soil type across many sites in boreal climate (Maljanen et al., 2010). We thus focus on the mineral soil sites that are better represented in our dataset.

\subsubsection{Nitrogen availability}

As expected, $\mathrm{N}$ addition had a positive effect on $\mathrm{N}_{2} \mathrm{O}$ emission across all four experiments (GS, KH, AT, KL), which was statistically significant at 3 out of 5 sites (Fig. 2). This suggests that $\mathrm{N}$ deposition could enhance $\mathrm{N}_{2} \mathrm{O}$ emissions, but the stepwise regression analysis did not give any explanatory power to $\mathrm{N}$ deposition (control plots, Fig. 2), as also observed by Pilegaard et al. (2006) for another European-wide dataset. Even the stepwise regression across all treatments including the relatively large $\mathrm{N}$ additions ( 35 to $50 \mathrm{~kg} \mathrm{~N} \mathrm{ha}^{-1} \mathrm{yr}^{-1}$ ) did not reveal an overall effect of $\mathrm{N}$ input (Table 4, Fig. 2), since the responses in $\mathrm{N}_{2} \mathrm{O}$ emissions to $\mathrm{N}$ addition were low compared to responses to other changes.

In the dataset compiled by Pilegaard et al. (2006), the C / N ratio of the top mineral soil was the best predictor of $\mathrm{N}_{2} \mathrm{O}$ emissions from forests on mineral soils. Likewise, our stepwise regression analyses for controls as well as for all plots underlined the role of mineral soil $\mathrm{C} / \mathrm{N}$ as a significant predictor of $\mathrm{N}_{2} \mathrm{O}$ fluxes (Table 4). In Fig. 4 we plotted control (filled symbols) and treatment (open symbols) data for $\mathrm{N}_{2} \mathrm{O}$ emission vs. mineral soil $\mathrm{C} / \mathrm{N}$ ratio (with sites identified by

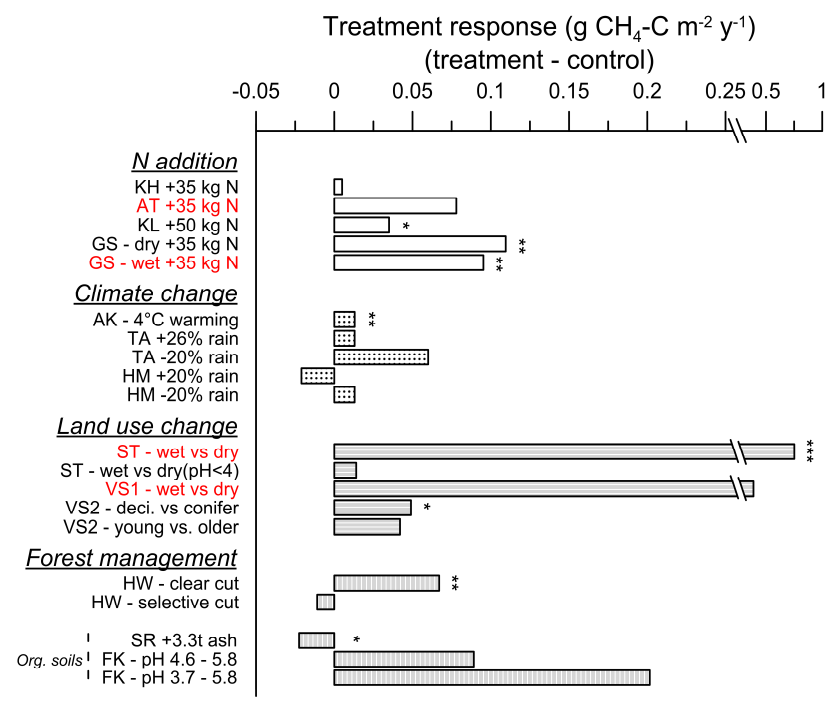

Fig. 3. Response of $\mathrm{CH}_{4}$ gas exchange to forest change (treatment minus control). Site codes and treatments are explained in Table 1. Stars indicate the level of significance for the treatment effect. $\left(^{*}\right.$ : $p<0.05$; $^{* *}: p<0.01$; $\left.^{* *}: p<0.001\right)$. A positive treatment response indicates that more $\mathrm{CH}_{4}$ is left in the atmosphere (i.e. a lower $\mathrm{CH}_{4}$ uptake occurred in the treatments compared to the controls). The text in red marks the sites that had $\mathrm{CH}_{4}$ emission (AT) or where the treatment resulted in a net $\mathrm{CH}_{4}$ emission (GS-wet, ST and VS1).

numbers). The relationship of the $\mathrm{N}_{2} \mathrm{O}$ emission to $\mathrm{C} / \mathrm{N}$ ratio in our data does not show up clearly in Fig. 4, probably due to interaction with other factors, mainly soil moisture and $\mathrm{pH}$. However, small $\mathrm{N}_{2} \mathrm{O}$ emissions were observed at $\mathrm{C} / \mathrm{N}$ ratio above 30, and $\mathrm{N}_{2} \mathrm{O}$ emissions were higher and more responsive to change at sites with lower $\mathrm{C} / \mathrm{N}$ ratios. No or low emissions were observed at some plots with $\mathrm{C} / \mathrm{N}$ below c. 20, if these plots were dry (TA), or with high soil $\mathrm{pH}$ (AT, VS1, VS2) or both (HM). One of the largest responses to change (dry to wet) was seen at the afforested site (VS2) with a $\mathrm{C} / \mathrm{N}$ ratio of 11 . A relationship between soil $\mathrm{C} / \mathrm{N}$ ratio on $\mathrm{N}_{2} \mathrm{O}$ emission was also found across a number of organic soils with a threshold for increased $\mathrm{N}_{2} \mathrm{O}$ emission at $\mathrm{C} / \mathrm{N}$ ratios around 20 to 25 (Klemedtsson et al., 2005; Maljanen et al., 2010). The $\mathrm{C} / \mathrm{N}$ ratio can be seen as a proxy for $\mathrm{N}$ availability. At high $\mathrm{C} / \mathrm{N}$ ratio, $\mathrm{N}$ immobilisation is dominating, but as $\mathrm{C} / \mathrm{N}$ ratio decreases net mineralisation increases, and below $\mathrm{C} / \mathrm{N}$ of 24-27 net nitrification occurs (Aber et al., 2003; Dannenmann et al., 2007; Kriebitzsch, 1978). With $\mathrm{N}_{2} \mathrm{O}$ emissions mainly coupled to nitrification and denitrification, the highest $\mathrm{N}_{2} \mathrm{O}$ fluxes should be expected when nitrate is formed and available at lower soil $\mathrm{C} / \mathrm{N}$ ratios $(<25)$, where also losses by nitrate leaching usually increase (Gundersen et al., 1998).

In forests, $\mathrm{N}$ losses to the atmosphere by $\mathrm{N}_{2} \mathrm{O}$ emission and $\mathrm{N}$ losses to the hydrosphere as leaching below the root zone are both preferentially occurring at low soil $\mathrm{C} / \mathrm{N}$ ratios 


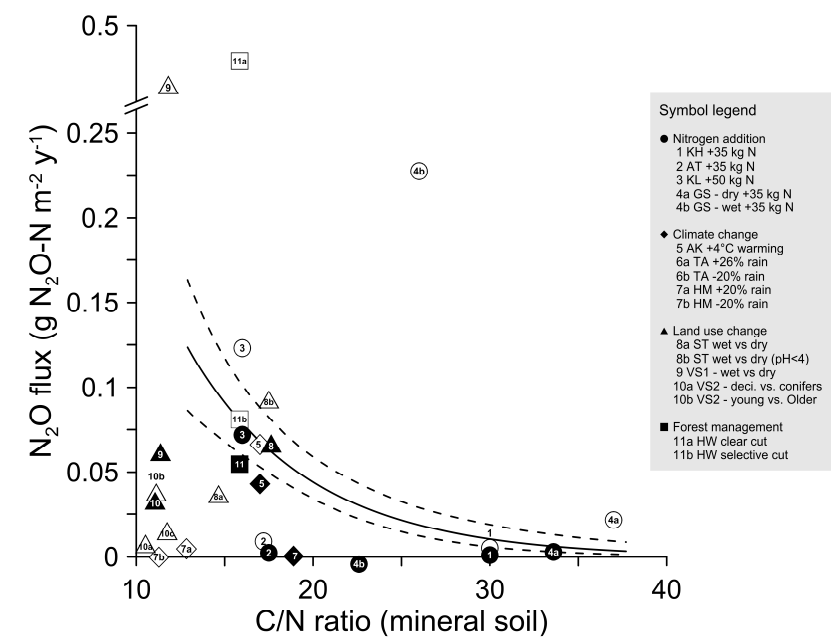

Fig. 4. $\mathrm{N}_{2} \mathrm{O}$ emission versus mineral soil $\mathrm{C} / \mathrm{N}$ ratio $(0-20 \mathrm{~cm})$ for control (filled symbols) and treatments (open symbols). Numbers in the symbols refer to sites and letters to treatments within site. Lines show the relationship (and its $95 \%$ confidence interval) found by $\mathrm{Pi}$ legaard et al. (2006). The types of forest change treatments are represented by different symbol shapes (circle: $\mathrm{N}$ addition; diamond: climate change; triangle: land-use change; square: forest management).

(high mineral $\mathrm{N}$ availability). Therefore, a correlation between the two types of $\mathrm{N}$ losses from the soil should be expected. We plotted $\mathrm{N}_{2} \mathrm{O}$ emissions and nitrate leaching data (where available) from our sites with other published data in Fig. 5. At low leaching rates $\left(<5 \mathrm{~kg} \mathrm{Nha}^{-1} \mathrm{yr}^{-1}\right)$, $\mathrm{N}_{2} \mathrm{O}$ emissions are mainly less than $0.05 \mathrm{~g} \mathrm{~N}_{2} \mathrm{O}-\mathrm{N} \mathrm{m}^{-2} \mathrm{yr}^{-1}$, and above this leaching rate the $\mathrm{N}_{2} \mathrm{O}$ emissions are above $0.05 \mathrm{~g} \mathrm{~N}_{2} \mathrm{O}-\mathrm{N} \mathrm{m}^{-2} \mathrm{yr}^{-1}$. Within individual sites, a clear relationship between $\mathrm{N}$ leaching and $\mathrm{N}_{2} \mathrm{O}$ emission was found for VS2 (Christiansen and Gundersen, 2011) and for the treatments with similar forest cover at HW (control and selective cut), plotted here for three individual years (20002002), where $\mathrm{N}_{2} \mathrm{O}$ emission doubled as nitrate leaching increased from 45 to $70 \mathrm{~kg} \mathrm{~N} \mathrm{ha}^{-1} \mathrm{yr}^{-1}$. However, the relationship across sites is not clear. The $\mathrm{N}$ losses from the clear-cut treatment at HW were obviously in another category, especially for the first two years with $\mathrm{N}$ leaching $>100 \mathrm{~kg} \mathrm{~N} \mathrm{ha}^{-1}$ $\mathrm{yr}^{-1}$ and $\mathrm{N}_{2} \mathrm{O}$ emission around $0.5 \mathrm{~g} \mathrm{~N}_{2} \mathrm{O}-\mathrm{N} \mathrm{m}^{-2} \mathrm{yr}^{-1}$. After the clear-cut, $\mathrm{N}$ availability was exceptionally high (no plant uptake), and soil moisture as well as seepage water flux was high due to low evapotranspiration, leading to large $\mathrm{N}$ losses to both the atmosphere and as leaching.

\subsubsection{Soil pH}

We observed a significant effect of soil $\mathrm{pH}$ together with soil moisture and $\mathrm{C} / \mathrm{N}$ ratio in the stepwise regression for all plots on mineral soil (Table 4). It is well known that $\mathrm{N}_{2} \mathrm{O}$ emissions increase at lower soil $\mathrm{pH}$ because the nitrous ox-

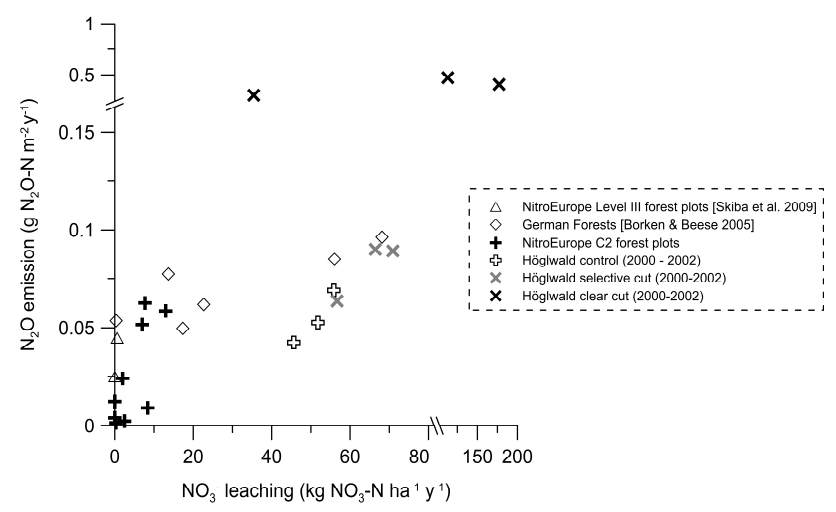

Fig. 5. Nitrogen losses from forest soils plotted as $\mathrm{N}_{2} \mathrm{O}$ emission versus $\mathrm{NO}_{3}^{-}$leaching below the root zone for forest change sites (crosses) and other European forests (see legend). Höglwald (HW) treatments are represented with data from 3 individual years, where nitrate leaching data were taken from Huber et al. (2004, 2010). Note the breaks on both axes.

ide reductase enzyme is inhibited, resulting in an increased $\mathrm{N}_{2} \mathrm{O} / \mathrm{N}_{2}$ ratio in the product of denitrification (Šimek and Cooper, 2002) and consequently leading to higher $\mathrm{N}_{2} \mathrm{O}$ production. Our data did not suggest a threshold soil $\mathrm{pH}$ for enhanced $\mathrm{N}_{2} \mathrm{O}$ emission, but treatment responses were larger at soil $\mathrm{pH}$ below 4 as was observed at the ST and FK sites (Christiansen et al., 2012; Weslien et al., 2009). The noticeable decline in emissions on the organic soil over the naturally increasing $\mathrm{pH}$ gradient at $\mathrm{FK}$ and the decline after wood ash application at SR (increasing soil $\mathrm{pH}$ by 0.3 units in the top $5 \mathrm{~cm}$ layer) again emphasises the importance of $\mathrm{pH}$, even if other parameters correlated more strongly with the $\mathrm{N}_{2} \mathrm{O}$ emission as well (Weslien et al., 2009).

\subsubsection{Soil moisture}

Soil moisture levels are known to control the magnitude of $\mathrm{N}_{2} \mathrm{O}$ emission originating from denitrification (e.g. Firestone and Davidson, 1989; Schaufler et al., 2010). Evidently, the temporal variation of soil moisture is an important factor for variability of $\mathrm{N}_{2} \mathrm{O}$ emissions (Kitzler et al., 2006; Christiansen et al., 2012), often with higher emissions in wet periods than dry (at the same temperature) as we also observed (data not shown). However, our study focused on whether forest change, as we defined earlier, leads to long-term effects or if it changes the average soil moisture content rather than the short-term effects of soil moisture variability.

In agreement with the existing knowledge, the stepwise regression revealed mean soil moisture as the most important parameter predicting $\mathrm{N}_{2} \mathrm{O}$ emissions (Table 4) across all treatments including wet forest areas. High emissions at wet, but not saturated, conditions are expected since the conditions for the anaerobic process of denitrification are favoured, as in the wetter soil oxygen consumption exceeds the supply due to inhibition of gas diffusion. For example, $\mathrm{N}_{2} \mathrm{O}$ 
emissions were reduced during very wet periods compared to the usual moist conditions at the AT site (data not shown). It is important to note that wet conditions (up to a certain level) may also indirectly increase the release of substrates $\left(\mathrm{NH}_{4}^{+}\right.$, $\mathrm{NO}_{3}^{-}$and organic $\mathrm{N}$ ) for $\mathrm{N}_{2} \mathrm{O}$ production. Furthermore, soil water content can control soil $\mathrm{pH}$ through the limitation of weathering processes and subsequent proton release (Szilas et al., 1998). Thus, soil moisture, rather than being only a direct effect, can also act as an indirect effect, influencing other important biogeochemical drivers of $\mathrm{N}_{2} \mathrm{O}$ exchange.

The interaction between enhanced soil moisture and $\mathrm{N}$ availability was most prominent at the three mineral soil sites with the largest treatment responses (GS wet, VS1, HW clear-cut; Fig. 2). As discussed above, increased $\mathrm{N}$ availability and higher soil moisture after clear-cut at HW gave the highest $\mathrm{N}_{2} \mathrm{O}$ response. A response almost as high as at HW clear-cut was observed over the hydrological gradient on a former fertilised arable soil (VS1). While we cannot directly assess how soil moisture and $\mathrm{N}$ availability interacted at that site, we can directly deduce how the addition of $\mathrm{N}$, at certain hydrological conditions, stimulated $\mathrm{N}_{2} \mathrm{O}$ production. Addition of $\mathrm{N}$ at GS gave a minor increase in the drier parts of the catchment, but a major increase in $\mathrm{N}_{2} \mathrm{O}$ emission from the wetter parts (Fig. 3).

\subsubsection{Climate change}

Even though the climatic conditions of the experimental sites of this study spanned from hemiboreal in Sweden to Mediterranean in Portugal, the large variation in treatment responses overshadowed any climatic effects. There was no influence of mean annual precipitation or mean annual air temperature on $\mathrm{N}_{2} \mathrm{O}$ fluxes. In contrast, increasing the soil temperature by $4^{\circ} \mathrm{C}$ in the growing season at the only site with experimental soil warming (AK) led to persistently elevated annual $\mathrm{N}_{2} \mathrm{O}$ emissions (Table 3, Fig. 2), probably related to enhanced microbial activity (Schindlbacher et al., 2009) and $\mathrm{N}$ turnover (Verburg et al., 1999).

At the water addition/exclusion sites (HM, TA), emulating changing precipitation patterns, only small and nonsignificant effects on $\mathrm{N}_{2} \mathrm{O}$ emission were found. However, addition of water temporarily stimulated $\mathrm{N}_{2} \mathrm{O}$ production at $\mathrm{HM}$, but the effect was not persistent throughout the measurement period (Shvaleva et al., 2011). As mentioned earlier, low emissions at HM may be an effect of higher $\mathrm{pH}$. The TA site was acidic ( $\mathrm{pH} 4$ ), but a detailed process study at the site showed a chemical inhibition of nitrification and denitrification as a reason for minor $\mathrm{N}_{2} \mathrm{O}$ emissions across all treatments (Castaldi et al., 2009).

\subsubsection{Synthesis}

Most of the considered forest change treatments increased $\mathrm{N}_{2} \mathrm{O}$ emission through changes in soil conditions (internal drivers) and their interactions (Fig. 6). A low $\mathrm{C} / \mathrm{N}$ ratio
$(<25)$, a proxy for high $\mathrm{N}$ availability, was, as expected, a prerequisite for significant $\mathrm{N}_{2} \mathrm{O}$ emission and for strong treatment responses (Fig. 4). However, emissions were not related to $\mathrm{N}$ deposition, although experimental $\mathrm{N}$ additions increased the emissions. Interactions with other soil conditions were, though, important. High $\mathrm{pH}$ (above $\approx 5$ in mineral soil) limited $\mathrm{N}_{2} \mathrm{O}$ emission, regardless of other favourable soil conditions. High soil water content is a key condition for the highest $\mathrm{N}_{2} \mathrm{O}$ emissions observed, often in interaction with high $\mathrm{N}$ availability. However, as soil water content approached saturation, the effect on $\mathrm{N}_{2} \mathrm{O}$ emission ceased, either due to reduced gas diffusion and/or due to complete reduction to $\mathrm{N}_{2}$ (Fig. 6). Soil temperature increased $\mathrm{N}_{2} \mathrm{O}$ emission - an effect that may in part be caused by stimulating $\mathrm{N}$ mineralisation and thus $\mathrm{N}$ availability, rather than just the temperature effect on microbial activity alone (Fig. 6).

\subsection{Emission factors for $\mathrm{N}_{2} \mathrm{O}$}

Quantification of the $\mathrm{N}$ deposition effect on $\mathrm{N}_{2} \mathrm{O}$ emission remains difficult, since other environmental conditions may also play a significant role. A default $\mathrm{N}_{2} \mathrm{O}$ emission factor of $1 \%$ of the $\mathrm{N}$ introduced to the system has been suggested for soils following $\mathrm{N}$ deposition in IPCC reporting guidelines (IPCC, 2006). Although a large variability in emissions from our assemblage of sites and treatments on mineral soils was detected, median and range of emission factors were $1.2 \%$ and $0-5 \%$ in control plots, and $1.7 \%$ and $0-32 \%$ for all plots, respectively. For the organic soils from Sweden, emission factors were $20-400 \%$, indicating that $\mathrm{N}$ deposition was not an important source of the $\mathrm{N}_{2} \mathrm{O}$ at these sites. In $\mathrm{N}$ addition sites, only $0.1 \%(\mathrm{KH})$ to $1 \%(\mathrm{KL})$ of $\mathrm{N}$ input was emitted as $\mathrm{N}_{2} \mathrm{O}$, with the exception of the wet parts of GS, where $5 \%$ of the added $\mathrm{N}$ was emitted back to the atmosphere. In a previous study along $\mathrm{N}$ deposition gradients from an ammonia source (poultry farm), it was estimated that $1.4 \%$ and $5.4 \%$ of the $\mathrm{N}$ deposition was returned to the atmosphere as $\mathrm{N}_{2} \mathrm{O}$ in coniferous and deciduous forest, respectively (Skiba et al., 2006).

Our data show that $\mathrm{N}_{2} \mathrm{O}$ emission factors vary considerably in both controls as well as across the entirety of plots. The variability of $\mathrm{N}_{2} \mathrm{O}$ emission factors was clearly increased by the manipulations, where the largest factor of $32 \%$, although transient, was found after the clear-cut at HW. A precise estimate of the emission factor from (semi-)natural ecosystems in a landscape or a region would have to take into account the extent of wet areas and organic soils with high emission strength as well as areas with wide $\mathrm{C} / \mathrm{N}$ ratio with low emission strength. Furthermore, temporary emission extremes would also have to be included. The $1 \%$ default $\mathrm{N}_{2} \mathrm{O}$ emission factor can only be taken as a rough estimate of indirect $\mathrm{N}_{2} \mathrm{O}$ emissions, but it is probably too low by a factor of two in comparison to what was measured at our sites as well as based on other estimation approaches 


\section{External drivers Internal drivers (soil) GHG response}

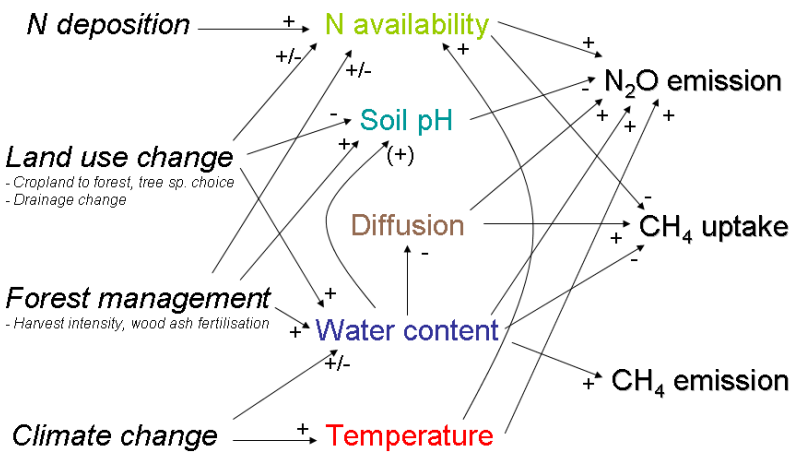

Fig. 6. Synthesis of the effects and interactions of forest change on GHG exchange observed in this study. Arrows starting from the external drivers denote those positive or negative impacts on internal drivers comprised in our study. The + or - signs at the arrows starting from an internal driver indicate the observed direction (increase or decrease) of the effect on GHG exchange (or the interaction on another internal driver) when the internal driver in question increases.

(Butterbach-Bahl et al., 2011a). Our findings underline the fact that default $\mathrm{N}_{2} \mathrm{O}$ emission factors are not able to capture the intrinsic feedback mechanisms between biogeochemical processes, especially when interacting with soil water and $\mathrm{N}$ availability, which can result in dramatic increases in $\mathrm{N}_{2} \mathrm{O}$ emissions.

\subsection{Factors controlling $\mathrm{CH}_{4}$ uptake or emission}

Much of the efforts in measuring and understanding $\mathrm{CH}_{4}$ exchange have been devoted to organic soils that often exhibit major emissions, but many forested organic soils show a net uptake of $\mathrm{CH}_{4}$ (Maljanen et al., 2010). This was also the case for the two Swedish organic soils investigated (SR, FK; Table 3). As for $\mathrm{N}_{2} \mathrm{O}$, in the following we focus on the results from mineral soils and the factors affecting $\mathrm{CH}_{4}$ exchange across our diverse assemblage of forest sites and treatments.

\subsubsection{Nitrogen availability and soil pH}

Similar to previous studies on the effect of nitrogen addition (Steudler et al., 1989; Liu and Greaver, 2009), all sites receiving additional $\mathrm{N}$ experienced a decrease in $\mathrm{CH}_{4}$ oxidation in the soil, although at only two of the sites responses were significant (Fig. 3). Ammonium can compete with $\mathrm{CH}_{4}$ for the enzyme methane mono-oxygenase, effectively lowering the oxidation of $\mathrm{CH}_{4}$ by methanotrophs in soil (Hanson and Hanson, 1996). The variable reduction of $\mathrm{CH}_{4}$ oxidation across the $\mathrm{N}$ addition sites indicates that other soil factors may be important as well. The significant influence of $\mathrm{C} / \mathrm{N}$ ratio on $\mathrm{CH}_{4}$ fluxes across all treatments (Table 4) also suggests an overall negative effect of $\mathrm{N}$ availability on $\mathrm{CH}_{4}$ oxidation.
Acidic conditions are assumed to be suboptimal for methanotrophs (Hanson and Hanson, 1996), but $\mathrm{CH}_{4}$ oxidation was observed in quite acidic soils such as the ST (Christiansen et al., 2012) and the HW (Butterbach-Bahl and Papen, 2002) sites. A positive effect of increasing $\mathrm{pH}$ was observed for the organic soils at the wood ash addition site (SR) as well as at the $\mathrm{pH}$ gradient site (FK), but for the mineral soils no clear $\mathrm{pH}$ effect could be identified (Table 4).

\subsubsection{Soil moisture and climate}

Soil moisture is one of the most important factors controlling $\mathrm{CH}_{4}$ dynamics in soils (Le Mer and Roger, 2001) due to the effect on both diffusion of $\mathrm{CH}_{4}$ within the soil matrix as well as the physiological stress excess or limited water exerts on methanotrophic bacteria. Also the promotion of $\mathrm{CH}_{4}$ production occurs at anaerobic conditions following saturation. We thus observed the largest response of $\mathrm{CH}_{4}$ fluxes in treatments involving water, and our stepwise regression analyses confirmed this (Table 4). Emissions of $\mathrm{CH}_{4}$ were, as expected, confined to very wet or water-saturated sites/treatments. A recent reassessment of the European $\mathrm{CH}_{4}$ budget showed that the inclusion of wet forest soils in the assessment doubled the estimated $\mathrm{CH}_{4}$ emissions from natural ecosystems (Grunwald et al., 2012), emphasising the importance of these soil types.

In the upland forest soils, higher soil water content might not per se reduce $\mathrm{CH}_{4}$ oxidation by affecting the activity of methanotrophic bacteria. Gas diffusion is proposed as one of the most important factors limiting $\mathrm{CH}_{4}$ uptake, and diffusivity is directly linked to soil water content by blocking pathways within the soil matrix (Dubbs and Whalen, 2010). Thus, it is likely that increased soil water content in soils that normally act as sinks, as after clear-cut at HW and in the gradient at VS1, limits $\mathrm{CH}_{4}$ oxidation simply by lowering the transport of atmospheric $\mathrm{CH}_{4}$ to the soil pore system. At $\mathrm{HW}$, increased $\mathrm{N}$ availability in combination with lower gas diffusion may explain the observed reduction in $\mathrm{CH}_{4}$ oxidation after clear-cut.

No consistent effect of precipitation or temperature could be observed across the sites, although the wettest site, AT with a MAP of $2300 \mathrm{~mm}$, was the only site showing a net $\mathrm{CH}_{4}$ emission. Changed precipitation regimes at the two Mediterranean sites (HM, TA) showed inconsistent and insignificant responses (Fig. 3). However, the measured uptake rates (0.19-0.24 $\mathrm{g} \mathrm{CH}_{4}-\mathrm{C} \mathrm{m}^{-2} \mathrm{yr}^{-1}$; Table 3) stress that, in dry ecosystems methanotrophs are present and active.

Increasing the soil temperature $\left(+4{ }^{\circ} \mathrm{C}\right.$ during the growing season) at the AK site significantly reduced $\mathrm{CH}_{4}$ oxidation (Table 3). However, considering that elevated soil temperatures may have stimulated $\mathrm{N}$ turnover, it is plausible that part of the reduction in $\mathrm{CH}_{4}$ oxidation represents a similar effect as observed for the $\mathrm{N}$ addition sites. 


\subsubsection{Synthesis}

Most of the forest change treatments investigated led to reduced uptake (lower $\mathrm{CH}_{4}$ oxidation) except for the wet-dry gradients (ST, VS1), where emission occurred at high soil moisture. Overall, our results indicate that soil water dynamics (through effects on gas diffusion) are crucial to $\mathrm{CH}_{4}$ fluxes (Fig. 6), and change of hydrological conditions is the single most important factor that controls the magnitude and direction of $\mathrm{CH}_{4}$ fluxes into and out of the soil. Increased $\mathrm{N}$ availability by forest change treatments (and between sites as indicated by an effect of soil $\mathrm{C} / \mathrm{N}$ ratio) also reduces the $\mathrm{CH}_{4}$ uptake (Fig. 6).

\subsection{Hot spots and hot changes - mitigation perspectives}

Prediction of GHG exchange in time and space as well as upscaling to national or continental scale remains challenging (e.g. Schulze et al., 2009). This challenge has been described to arise from the fact that hot spots (small areas) and hot moments (brief periods) frequently account for much of the $\mathrm{N}_{2} \mathrm{O}$ gas exchange (Groffman et al., 2009), and the same is true for $\mathrm{CH}_{4}$ (Grunwald et al., 2012). Our study added shortand long-term effects of forest change to this complexity, and some of our forest treatments (hot changes) even altered the GHG exchange orders of magnitude compared to the control (Table 3). "Hot changes" are related to the wet and temporary wet areas that are also "hot spots" within forests, but also $\mathrm{N}$ deposition, forest management and soil warming affected soil GHG exchange significantly.

Most of the investigated treatments increased the net loading of GHG to the atmosphere (cf. Figs. 2 and 3) because of the increased emissions or the reduced uptake for $\mathrm{N}_{2} \mathrm{O}$ and $\mathrm{CH}_{4}$, respectively. Only for three treatments the responses had the opposite direction for the two gases, but in these cases the responses were relatively small. For example, older afforested stands emitted more $\mathrm{N}_{2} \mathrm{O}$ than younger stands (site VS2), but older stands had a higher $\mathrm{CH}_{4}$ uptake rate. Another more important trade-off between the gases was observed in the dry-wet gradients (site ST, VS1): Emissions of $\mathrm{N}_{2} \mathrm{O}$ did increase in the wet parts of these gradients but became negligible at water-saturated conditions (Christiansen et al., 2012), where in contrast $\mathrm{CH}_{4}$ emissions increased considerably.

The similarity in response to treatments indicates a correspondence in the soil factors regulating the soil-atmosphere exchange of these two gases as illustrated in Fig. 6. A synergistic effect of $\mathrm{N}$ availability and soil water content on $\mathrm{N}_{2} \mathrm{O}$ emission was shown by $\mathrm{N}$ addition in the wet parts of GS, and was also demonstrated by the major response of $\mathrm{N}_{2} \mathrm{O}$ emissions to clear-cutting at $\mathrm{HW}$.

Considering the 12-fold larger warming potential of $\mathrm{N}_{2} \mathrm{O}$ compared to $\mathrm{CH}_{4}$, most emphasis should be on $\mathrm{N}_{2} \mathrm{O}$ with respect to controls on emissions and to mitigation efforts. However, for the majority of forest change treatments inves- tigated, the direction of the response was the same for both gasses, generally reducing the overall GHG sink strength of forests.

The two organic soils studied confirm that peatlands, and particularly those on afforested former agricultural soils, are hot spots (Maljanen et al., 2010) and are highly sensitive to changes in soil conditions. The fertile FK site with some of the highest fluxes of both gases may be a special example, however, confirming the importance of $\mathrm{C} / \mathrm{N}$ ratio and $\mathrm{pH}$ (Klemedtsson et al., 2005) in controlling the GHG exchange from organic soils. Forests with complex topography may have wet and temporarily wet areas that may comprise a major part of the GHG exchange, even though they only represent a small fraction of the area (Christiansen et al., 2012; Grunwald et al., 2012). Increased winter precipitation, as foreseen for this century at northern latitudes in Europe, may enhance this phenomenon by increasing the endurance of wet areas especially in poorly and moderately drained soils. Moreover, increasing soil moisture in some periods may increase the overall soil GHG emissions.

The most responsive sites, next to those on wet soils, were those with low soil $\mathrm{C} / \mathrm{N}$ ratio and low soil $\mathrm{pH}$. Thus, resilient ecosystems with respect to soil GHG exchange are forests with well drained soils with high $\mathrm{C} / \mathrm{N}$ ratio $(>25)$ or high soil $\mathrm{pH}(>5)$. Much of the boreal forests and forests planted on heathlands in NW Europe have high $\mathrm{C} / \mathrm{N}$ ratio and thus persistently low $\mathrm{N}_{2} \mathrm{O}$ emissions are expected. Also, the dry Mediterranean forests are resilient ecosystems concerning GHG emissions, since the rainfall exclusion/addition had no effects on GHG exchange, although water was expected to be a limiting factor.

Mitigation strategies may focus on (i) management of wet forest areas and forested peatlands, (ii) continuous forest cover management, (iii) reducing $\mathrm{N}$ availability, and (iv) avoiding anthropogenic soil acidification, e.g. by acid inputs or excessive biomass removal.

Management of the water level or restoration of natural hydrology may be used to reduce $\mathrm{N}_{2} \mathrm{O}$ emissions from drained peatlands and other wet areas by increasing the area of water saturated zones. However, there may be a trade-off with increasing $\mathrm{CH}_{4}$ emissions. A better knowledge of the hydrological interactions with GHG dynamics in forests will be imperative to foster wise management.

In N-saturated (such as HW) or naturally fertile forests, clear-cuts should be avoided by using continuous forest cover management systems. We recommend this, even though the observed effects on GHG exchange of a clear-cut were transient, but with the magnitude of the responses they still have importance on a rotation scale. In N-rich systems, an increase in biomass removal (harvesting whole trees or more of the $\mathrm{N}$ rich parts of the trees) may alleviate the $\mathrm{N}$ excess in the soil and reduce GHG emissions. However, care should be taken not to deplete other nutrients, or they should be returned by wood ash application. Wood ash application, slightly increasing the $\mathrm{pH}$ (Klemedtsson et al., 2010) is yet again a 
mitigation option. For example, it was the one treatment that mitigated emission of both gases the most. Thus, management of forest bioenergy production systems in N-rich sites should aim at removing excess $\mathrm{N}$ and compensating other nutrients through addition of ash products, thereby not only reducing the GHG emissions by substituting fossil fuels but also by reducing the non- $\mathrm{CO}_{2}$ GHG fluxes from forest soils.

Acknowledgements. This study was funded by the NitroEurope IP under the EC 6th Framework Programme (Contract No. 017841).

Edited by: U. Skiba

\section{References}

Aber, J. D., Goodale, C. L., Ollinger, S. V., Smith, M.-L., Magill, A. H., Martin, M. E., Hallett, R. A., and Stoddard, J. L.: Is Nitrogen Deposition Altering the Nitrogen Status of Northeastern Forests?, BioScience, 53, 375-389, 2003.

Ball, B. C., Smith, K. A., Klemedtsson, L., Brumme, R., Sitaula, B. K., Hansen, S., Prieme, A., MacDonald, J., and Horgan, G. W.: The influence of soil gas transport properties on methane oxidation in a selection of northern European soils, J. Geophys. Res.Atmos., 102, 23309-23317, 1997.

Borken, W. and Beese, F.: Control of nitrous oxide emissions in European beech, Norway spruce and Scots pine forests, Biogeochemistry, 76, 141-159, 2005.

Butterbach-Bahl, K. and Papen, H.: Four years continuous record of $\mathrm{CH}_{4}$-exchange between the atmosphere and untreated and limed soil of a N-saturated spruce and beech forest ecosystem in Germany, Plant Soil, 240, 77-90, 2002.

Butterbach-Bahl, K., Nemitz, E., Zaehle, S., Billen, G., Boeckx, P., Erisman, J. W., Garnier, J., Upstill-Goddard, R., Kreuzer, M., Oenema, O., Reis, S., Schaap, M., Simpson, D., de Vries, W., Winiwarter, W., and Sutton, M. A.: Nitrogen as a threat to the European greenhouse balance, in: The European Nitrogen Assessment: Sources, Effects and Policy Perspectives, Cambridge University Press, 434-462, 2011a.

Butterbach-Bahl, K., Gundersen, P., Ambus, P., Augustin, J., Beier, C., Boeckx, P., Dannenmann, M., Gimeno, B. S., Kiese, R., Kitzler, B., Ibrom, A., Rees, R. M., Smith, K. A., Stevens, C., Vesala, T., and Zechmeister-Boltenstern, S.: Nitrogen processes in terrestrial ecosystems, in: The European Nitrogen Assessment: Sources, Effects and Policy Perspectives, Cambridge University Press, 99-125, 2011b.

Castaldi, S., Carfora, A., Fiorentino, A., Natale, A., Messere, A., Miglietta, F., and Cotrufo, M. F.: Inhibition of net nitrification activity in a Mediterranean woodland: possible role of chemicals produced by Arbutus unedo, Plant Soil, 15, 273-283, 2009.

Christiansen, J. R.: Greenhouse gas exchange and nitrogen loss under forest change - The role of tree species, land use history and wet forest soils, Ph.D. Thesis, University of Copenhagen, Denmark, 217 pp., 2010.

Christiansen, J. R. and Gundersen, P.: Stand age and tree species affect $\mathrm{N}_{2} \mathrm{O}$ and $\mathrm{CH}_{4}$ exchange from afforested soils, Biogeosciences, 8, 2535-2546, doi:10.5194/bg-8-2535-2011, 2011a.

Christiansen, J. R., Korhonen, J. F. J., Juszczak, R., Giebels, M., and Pihlatie, M.: Assessing the effects of chamber placement, manual sampling and headspace mixing on $\mathrm{CH}_{4}$ fluxes in a laboratory experiment, Plant Soil, 343, 171-185, 2011 b.

Christiansen, J. R., Vesterdal, L., and Gundersen, P.: Nitrous oxide and methane exchange in two small temperate forest catchments - effects of hydrological gradients and implications for global warming potentials of forest soils, Biogeochemistry, 107, 437454, 2012.

Cotrufo, M. F., Alberti, G., Inglima, I., Marjanović, H., LeCain, D., Zaldei, A., Peressotti, A., and Miglietta, F.: Decreased summer drought affects plant productivity and soil carbon dynamics in a Mediterranean woodland, Biogeosciences, 8, 2729-2739, doi:10.5194/bg-8-2729-2011, 2011.

Dannenmann, M., Gasche, R., and Papen, H.: Nitrogen turnover and $\mathrm{N}_{2} \mathrm{O}$ production in the forest floor of beech stands as influenced by forest management, J. Plant Nutr. Soil Sc., 170, 134-144, 2007.

Dubbs, L. L. and Whalen, S. C.: Reduced net atmospheric $\mathrm{CH}_{4}$ consumption is a sustained response to elevated $\mathrm{CO}_{2}$ in a temperate forest, Biol. Fert. Soils, 46, 597-606, 2010.

Firestone, M. K. and Davidson, E. A.: Microbial basis of NO and $\mathrm{N}_{2} \mathrm{O}$ production and consumption in soil, in: Exchange of trace gases between terrestrial ecosystems and the atmosphere, edited by: Andreae, M. O. and Schimel, D. S., John Wiley \& Sons Ltd., Chichester, UK, 7-21, 1989.

Groffman, P. M., Butterbach-Bahl, K., Fulweiler, R. W., Gold, A. J., Morse, J. L., Stander, E. K., Tague, C., Tonitto, C., and Vidon, P.: Challenges to incorporating spatially and temporally explicit phenomena (hotspots and hot moments) in denitrification models, Biogeochemistry, 93, 49-77, 2009.

Grunwald, D., Fender, A.-C., Erasmi, S., and Jungkunst, H. F.: Towards improved bottom-up inventories of methane from the European land surface, Atmos. Environ., 51, 203-211, 2012.

Gundersen, P.: Effects of enhanced nitrogen deposition in a spruce forest at Klosterhede, Denmark, examined by $\mathrm{NH}_{4} \mathrm{NO}_{3}$ addition, Forest Ecol. Manag., 101, 251-268, 1998.

Gundersen, P., Callesen, I., and de Vries, W.: Nitrate leaching in forest ecosystems is controlled by forest floor $\mathrm{C} / \mathrm{N}$ ratio, Environ. Pollut., 102, 403-407, 1998.

Hagedorn, F., Schleppi, P., Bucher, J., and Fluhler, H.: Retention and leaching of elevated $\mathrm{N}$ deposition in a forest ecosystem with Gleysols, Water Air Soil Poll., 129, 119-142, 2001.

Hansen, K., Rosenqvist, L., Vesterdal, L., and Gundersen, P.: Nitrate leaching from three afforestation chronosequences on former arable land in Denmark, Global Change Biol., 13, 12501264, 2007.

Hanson, R. S. and Hanson, T. E.: Methanotrophic bacteria, Microbiol. Rev., 60, 439-471, 1996.

Huber, C., Weis, W., Baumgarten, M., and Göttlein, A.: Spatial and temporal variation of seepage water chemistry after femel and small scale clear-cutting in a N-saturated Norway spruce stand, Plant Soil, 267, 23-40, 2004.

Huber, C., Aherne, W. W., Farrell, E. P., Göttlein, A., and Cummins, T.: Ion concentrations and fluxes of seepage water before and after clear cutting of Norway spruce stands at Ballyhooly, Ireland, and Höglwald, Germany, Biogeochemistry, 101, 7-26, 2010.

IPCC: Guidelines for National Greenhouse Gas Inventories, Vol. 4, Chap. 11, IGES, Hayama, Japan, 2006.

Kaiser, C., Koranda, M., Kitzler, B., Schnecker, J., Schweiger, P., Fuchslueger, L., Rasche, F., Zechmeister-Boltenstern, S., Ses- 
sitsch, A., and Richter, A.: Belowground carbon allocation by trees drive seasonal patterns of extracellular enzyme activities by altering microbial community composition in a beech forest soil, New Phytol., 187, 843-858, 2010.

Kitzler, B., Zechmeister-Boltenstern, S., Holtermann, C., Skiba, U., and Butterbach-Bahl, K.: Controls over $\mathrm{N}_{2} \mathrm{O}, \mathrm{NO}_{\mathrm{x}}$ and $\mathrm{CO}_{2}$ fluxes in a calcareous mountain forest soil, Biogeosciences, 3 , 383-395, doi:10.5194/bg-3-383-2006, 2006.

Klemedtsson, L., Klemedtsson, Å. K., Moldan, F., and Weslien, P.: Nitrous oxide emmision from Swedish forest soils in relation to liming and simulated increased N-deposition, Biol. Fertil. Soil. 25, 290-295, 1997.

Klemedtsson, L., von Arnold, K., Weslien, P., and Gundersen, P.: Soil $\mathrm{CN}$ ratio as scalar parameter to predict nitrous oxide emissions, Global Change Biol., 11, 1-6, 2005.

Klemedtsson, L., Ernfors, M., Björk, R. G., Weslien, P., Rütting, T., Crill, P., and Sikström, U.: Reduction of greenhouse gas emissions by wood ash application to a Picea abies forest on a drained organic soil, Eur. J. Soil Sci., 61, 734-744, 2010.

Kriebitzsch, W. U.: Stickstoffnachlieferung in sauren Waldböden Nordwestdeutschlands, Scripta Geobotanica, Goltze, Göttingen, Germany, 14, 1-66, 1978.

Kroon, P. S., Hensen, A., Van den Bulk, W. C. M., Jongejan, P. A. C., Vermeulen, A. T.: The importance of reducing the systematic error duet o non-linearity in $\mathrm{N}_{2} \mathrm{O}$ flux measurements by static chambers, Nutr. Cycl. Agroecosyst. 82, 175-186, 2008.

Le Mer, J. and Roger, P.: Production, oxidation, emission and consumption of methane by soils: A review, Eur. J. Soil Biol., 37, 25-50, 2011.

Liu, L. and Greaver, T. L.: Nitrogen addition stimulates emissions of biogenic greenhouse gases in terrestrial and wetland ecosystems, Ecol. Lett., 12, 1103-1117, 2009.

Luyssaert, S., Ciais, P., Piao, S. L., Schulze, E.-D., Jung, M., Zaehle, S., Schelhaas, M. J., Reichstein, M., Churkina, G., Papale, D., Abril, G., Beer, C., Grace, J., Loustau, D., Matteucci, G., Magnani, F., Nabuurs, G. J., Verbeeck, H., Sulkava, M., van der Werf, G. R., and Janssens, I. A.: The European carbon balance. Part 3: forests, Global Change Biol., 16, 1429-1450, 2010.

Machefert, S. E., Dise, N. B., Goulding, K. W. T., and Whitehead, P. G.: Nitrous oxide emission from a range of land uses across Europe, Hydrol. Earth Syst. Sc., 6, 325-337, 2002.

Maljanen, M., Sigurdsson, B. D., Gudmundsson, J., Óskarsson, H., Huttunen, J. T., and Martikainen, P. J.: Greenhouse gas balances of managed peatlands in the Nordic countries - present knowledge and gaps, Biogeosciences, 7, 2711-2738, doi:10.5194/bg7-2711-2010, 2010.

Moldan, F. and Wright, R. F.: Nitrogen leaching and acidification during 19 years of $\mathrm{NH}_{4} \mathrm{NO}_{3}$ additions to a coniferous-forested catchment at Gårdsjön, Sweden (NITREX), Environ. Pollut., 159, 431-440, 2011.

Pilegaard, K., Skiba, U., Ambus, P., Beier, C., Brüggemann, N., Butterbach-Bahl, K., Dick, J., Dorsey, J., Duyzer, J., Gallagher, M., Gasche, R., Horvath, L., Kitzler, B., Leip, A., Pihlatie, M. K., Rosenkranz, P., Seufert, G., Vesala, T., Westrate, H., and Zechmeister-Boltenstern, S.: Factors controlling regional differences in forest soil emission of nitrogen oxides ( $\mathrm{NO}$ and $\mathrm{N}_{2} \mathrm{O}$ ), Biogeosciences, 3, 651-661, doi:10.5194/bg-3-651-2006, 2006.

Rochette, P. and Eriksen-Hamel, N. S.: Chamber measurements of soil nitrous oxide flux: Are absolute values reliable?, Soil Sci.
Soc. Am. J., 72, 331-342, 2008.

Schachtschabel, P.: Methodenvergleich zur pH-Bestimmung von Böden, Z. Pflanz. Bodenkunde, 130, 37-43, 1971.

Schaufler, G., Kitzler, B., Schindlbacher, A., Skiba, U., Sutton, M. A., and Zechmeister-Boltenstern, S.: Greenhouse gas emissions from European soils under different land use: effects of soil moisture and temperature, Eur. J. Soil Sci., 61, 1365-2389, 2010.

Schindlbacher, A., Zechmeister-Boltenstern, S., and Jandl, R.: Carbon losses due to soil warming: Do autotrophic and heterotrophic soil respiration respond equally?, Global Change Biol., 15, 901913, 2009.

Schindlbacher, A., Rodler, A., Kuffner, M., Kitzler, B., Sessitsch, A., and Zechmeister-Boltenstern, S.: Experimental warming effects on the microbial community of a temperate mountain forest soil, Soil Biol. Biochem., 43, 1417-1425, 2011.

Schulze, E. D., Luyssaert, S., Ciais, P., Freibauer, A., Janssens, I. A., Soussana, J. F., Smith, P., Grace, J., Levin, I., Thiruchittampalam, B., Heimann, M., Dolman, A. J., Valentini, R., Bousquet, P., Peylin, P., Peters, W., Roedenbeck, C., Etiope, G., Vuichard, N., Wattenbach, M., Nabuurs, G. J., Poussi, Z., Nieschulze, J., and Gash, J. H.: Importance of methane and nitrous oxide for Europe's terrestrial greenhouse-gas balance, Nature Geosci., 2, 842-850, 2009.

Skiba, U., Dick, J., Storeton-West, R., Lopez-Fernandez, S., Woods, C., Tang, S., and vanDijk, N.: The relationship between $\mathrm{NH}_{3}$ emissions from a poultry farm and soil $\mathrm{NO}$ and $\mathrm{N}_{2} \mathrm{O}$ fluxes from a downwind forest, Biogeosciences, 3, 375-382, doi:10.5194/bg3-375-2006, 2006.

Skiba, U., Drewer, J., Tang, Y. S., van Dijk, N., Helfter, C., Nemitz, E., Famulari, D., Cape, J. N., Jones, S. K., Twigg, M., Pihlatie, M., Vesala, T., Larsen, K. S., Carter, M. S., Ambus, P., Ibrom, A., Beier, C., Hensen, A., Frumau, A., Erisman, J. W., Brüggemann, N., Gasche, R., Butterbach-Bahl, K., Neftel, A., Spirig, C., Horvath, L., Freibauer, A., Cellier, P., Laville, P., Loubet, B., Magliulo, E., Bertolini, T., Seufert, G., Andersson, M., Manca, G., Laurila, T., Aurela, M., Lohila, A., ZechmeisterBoltenstern, S., Kitzler, B., Schaufler, G., Siemens, J., Kindler, R., Flechard, C., and Sutton, M. A.: Biosphere-atmosphere exchange of reactive nitrogen and greenhouse gases at the NitroEurope core flux measurement sites: Measurement strategy and first data sets, Agr. Ecosyst. Environ., 133, 139-149, 2009.

Shvaleva, A., Lobo-do-Vale, R., Cruz, C., Castaldi, S., Rosa, A. P., Chaves, M. M., and Pereira, J. S.: Soil-atmosphere greenhouse gases $\left(\mathrm{CO}_{2}, \mathrm{CH}_{4}\right.$ and $\left.\mathrm{N}_{2} \mathrm{O}\right)$ exchange in an evergreen oak woodland in southern Portugal, Plant Soil Environ., 57, 471-477, 2011.

Šimek, M. and Cooper, J. E.: The influence of soil pH on denitrification: progress towards the understanding of this interaction over the last 50 years, Eur. J. Soil Sci., 53, 345-354, 2002.

Steudler, P. A., Bowden, R. D., Melillo, J. M., and Aber, J. D.: Influence of Nitrogen-Fertilization on Methane Uptake in Temperate Forest Soils, Nature, 341, 314-316, 1989.

Sutton, M. A., Howard, C. M., Erisman, J. W., Billen, G., Bleeker, A., Grennfelt, P., van Grinsven, H., and Grizzetti, B.: The European Nitrogen Assessment: Sources, Effects and Policy Perspectives, Cambridge University Press, Cambridge, 2011.

Szilas, C. P., Borggaard, O. K., Hansen, H. C. B., and Rauer, J.: Potential iron and phosphate mobilization during flooding of soil material, Water Air Soil Poll., 106, 97-109, 1998. 
Verburg, P. S. J., Van Dam, D., Hefting, M. M., and Tietema, A.: Microbial transformations of $\mathrm{C}$ and $\mathrm{N}$ in a boreal forest floor as affected by temperature, Plant Soil, 208, 187-197, 1999.

Weslien, P., Klemedtsson, A. K., Borjesson, G., and Klemedtsson, L.: Strong $\mathrm{pH}$ influence on $\mathrm{N}_{2} \mathrm{O}$ and $\mathrm{CH}_{4}$ fluxes from forested organic soils, Eur. J. Soil Sci., 60, 311-320, 2009.

WMO: World Meteorological Organisation Greenhouse gas bulletin - The State of Greenhouse Gases in the Atmosphere Based on Global Observations through 2009, available at: http://www.wmo.int/pages/prog/arep/gaw/ghg/documents/ GHG_bull_6en.pdf, United Nations, Geneva, 2010.

Wright, R. F., Roelofs, J. G. M., Bredemeier, M., Blanck, K., Boxman, A. W., Emmett, B. A., Gundersen, P., Hultberg, H., Kjønaas, O. J., Moldan, F., Tietema, A., Van Breemen, N., and
Van Dijk, H. F. G.: NITREX: response of coniferous forest ecosystems to experimentally-changed deposition of nitrogen, Forest Ecol. Manag., 71, 163-169, 1995.

Wu, X., Brüggemann, N., Gasche, R., Shen, Z., Wolf, B., and Butterbach-Bahl, K.: Environmental controls over soilatmosphere exchange of $\mathrm{N}_{2} \mathrm{O}, \mathrm{NO}$, and $\mathrm{CO}_{2}$ in a temperate Norway spruce forest, Global Biogeochem. Cy., 24, GB2012, doi:10.1029/2009GB003616, 2010.

Wu, X., Brüggemann, N., Gasche, R., Papen, H., Willibald, G., and Butterbach-Bahl, K.: Long-term effects of clear-cutting and thinning on soil methane fluxes in a temperate spruce forest in southern Germany, Environ. Pollut., 159, 2467-2475, 2011. 